\title{
Earth Observation for agricultural drought monitoring in the Pannonian Basin (southeastern Europe): current state and future directions
}

\author{
Laura Crocetti ${ }^{1}$ (D) $\cdot$ Matthias Forkel $^{2} \cdot$ Milan Fischer $^{3} \cdot$ František Jurečka $^{3}$ - Aleš Grlj ${ }^{4,5}$ - Andreas Salentinig ${ }^{1}$. \\ Miroslav Trnka ${ }^{3,6} \cdot$ Martha Anderson $^{7} \cdot$ Wai-Tim Ng $^{8} \cdot$ Žiga Kokalj $^{4,5} \cdot$ Andreea Bucur $^{1} \cdot$ Wouter Dorigo $^{1}$
}

Received: 23 May 2020 / Accepted: 10 October 2020 / Published online: 28 October 2020

(C) The Author(s) 2020

\begin{abstract}
The Pannonian Basin in southeastern Europe is heavily used for rain-fed agriculture. The region experienced several droughts in the last years, causing major yield losses. Ongoing climate change, characterised by increasing temperatures and potential evapotranspiration, and by changes in precipitation distribution will likely increase the frequency and intensity of drought episodes in the future. Hence, ongoing monitoring of droughts and estimation of their impact on agriculture is necessary to adapt agricultural practices to changing weather and climate extremes. Several regional initiatives, projects and online tools have been established to facilitate drought monitoring and management in the Pannonian Basin. However, reliable systems to forecast potential drought impacts on plant productivity and agricultural yields at monthly to seasonal scales are only in their infancy, as plant response to climatic extremes is still poorly understood. With the increasing availability of high-resolution and long-term Earth Observation (EO) data and recent progress in machine learning and artificial intelligence, further improvements in drought monitoring and impact prediction capacities are expected. Here we review the current state of drought monitoring in the Pannonian Basin, identify EO-based variables to potentially improve regional drought impact monitoring and outline future perspectives for seasonal forecasts of drought impacts on agriculture.
\end{abstract}

Keywords Pannonian Basin · Earth Observation $\cdot$ Agricultural drought $\cdot$ Machine learning

Communicated by Wolfgang Cramer

Laura Crocetti

laura.crocetti@geo.tuwien.ac.at

Matthias Forkel

matthias.forkel@tu-dresden.de

Milan Fischer

fischer.milan@gmail.com

František Jurečka

frantisek.jurecka@centrum.cz

Aleš Grlj

ales.grlj@space.si

Andreas Salentinig

andreas.salentinig@geo.tuwien.ac.at

\author{
Miroslav Trnka \\ mirek_trnka@yahoo.com \\ Martha Anderson \\ martha.anderson@usda.gov \\ Wai-Tim Ng \\ tim.ng@eodc.eu \\ Žiga Kokalj \\ ziga.kokalj@zrc-sazu.si \\ Andreea Bucur \\ andreea.bucur@gmail.com \\ Wouter Dorigo \\ wouter.dorigo@geo.tuwien.ac.at
}

Extended author information available on the last page of the article 


\section{Introduction}

\section{Drought mechanisms}

Droughts are complex phenomena that can have an enormous impact on the environment, economy and society. Droughts are usually driven by a lack of precipitation and/or increased atmospheric water demand, which causes a shortage of water for plant growth, river runoff, inland ship trafficking or other use of water resources (Wilhite and Glantz 1985). Depending on the duration, effects and intensity, drought can be classified into four types: meteorological, agricultural, hydrological and socio-economic drought (Fig. 1). The first three types deal with the physical phenomenon, while the last one is associated with the impacts of drought on society. All types of drought are closely related. Therefore, oftentimes, it is difficult to distinguish between the different types as there is no definition or measurement of when one type of drought transforms into another. A meteorological drought is typically indicated by a period of precipitation deficit over a region of interest. In combination with increased atmospheric evaporative demand, e.g. by high temperatures, high solar radiation and wind, soil moisture levels may drop and cause agricultural drought, which is reflected in decreased photosynthesis and transpiration and, hence, decreased plant productivity. Ongoing depletion of soil and groundwater reserves may eventually lead to a hydrological drought, which is characterised by a reduced amount of water in streams, lakes, wetlands, reservoirs and groundwater tables. If these conditions lead to a failure of water resource systems to meet water demands, it is called a socio-economic drought (Mishra and Singh 2010).

Droughts often co-occur with other extremes like heat waves (Mazdiyasni and AghaKouchak 2015; Zscheischler et al. 2018) or atmospheric aridity (high vapour pressure deficit) (Zhou et al. 2019), which intensify the drought. These compound droughts have negative impacts on plants (e.g. stomatal closure, increase of respiration, reduction of net assimilation) and ecosystems (e.g. reduction of evapotranspiration, gross and net primary productivity), and self-intensify via various positive feedbacks (e.g. reduction of evaporative cooling and decrease of precipitation and cloudiness) (Katul et al. 2012; Sippel et al. 2018; Miralles et al. 2019). Droughts and heat waves can also trigger the occurrence of other disturbances such as wildfires and insect outbreaks and lead to other environmental, economic and societal impacts (Zscheischler et al. 2018; Forkel et al. 2019).

\section{Monitoring drought}

Drought monitoring refers to the continuous collection and analysis of drought indicators that assist decision-makers by providing information regarding the onset and development of droughts (Wilhite 2000). The first, small-scale drought monitoring systems were based on in situ measurements of environmental variables such as precipitation, temperature, discharge and groundwater level. These variables were either used directly or indirectly, i.e. in the form of anomalies from the climatological mean conditions.

Large-scale drought monitoring began with the introduction of more complex indices such as the Palmer Drought Severity Index (Palmer 1965), Self-Calibrating Palmer Drought Severity Index (Wells et al. 2004), Surface Water Supply Index (Shafer and Dezman 1982), Standardized Precipitation Index (SPI) (McKee et al. 1993), and Standardized Precipitation Evapotranspiration Index (SPEI) (Vicente-Serrano et al. 2009). These indices typically ingest gridded terrestrial meteorological datasets. Some of these indices are widely used by regional and national meteorological and hydrological institutions to observe meteorological drought. However, they do not resolve local surface characteristics or provide information regarding drought effects on vegetation, since the actual soil moisture available for plant growth is only represented indirectly. Moreover, the quality
Fig. 1 Types of drought: meteorological, agricultural, hydrological and socio-economic drought with their major triggers and impacts

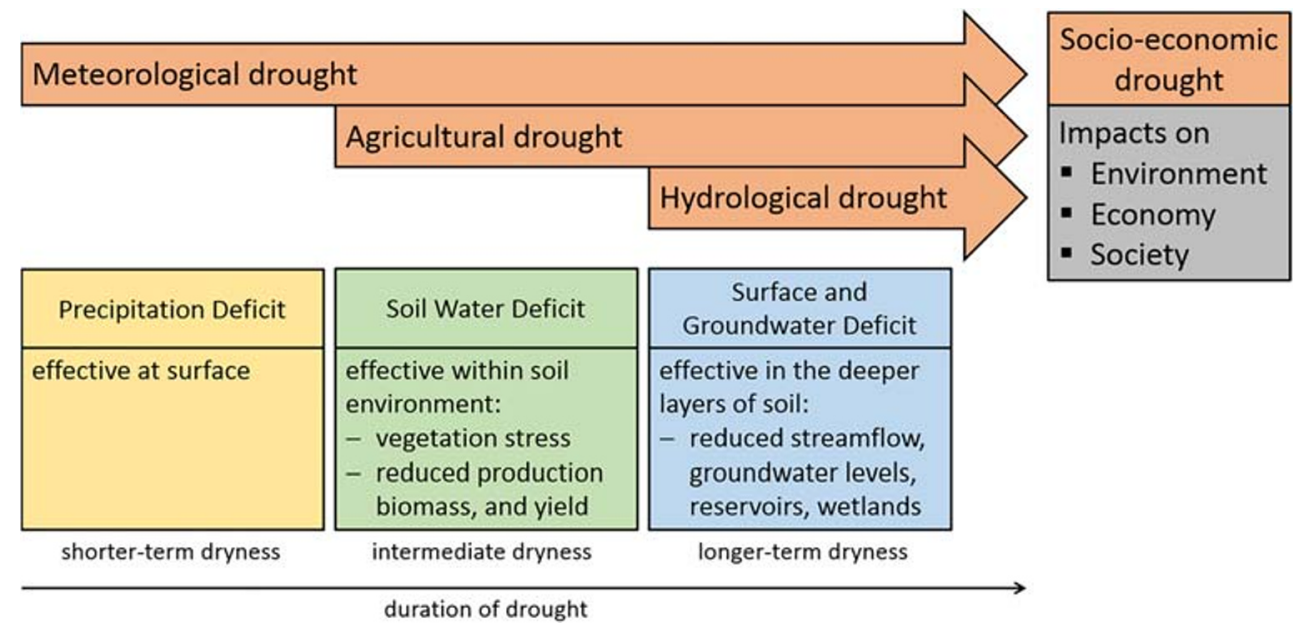


and spatial availability of the in situ measurements that are typically used to feed these indices strongly differ.

Advances in remote sensing technologies revolutionised the field of drought monitoring by enabling continuous observations of key drought-related variables over large spatial and temporal scales (West et al. 2019) (see the "Earth Observation-based drought monitoring" section). Remote sensing data have improved the ability to track drought, particularly in data-poor regions, by providing estimates of surface soil moisture, evapotranspiration or vegetation state (Anderson et al. 2007; Du et al. 2013; Enenkel et al. 2016). Several EO-based indicators have been incorporated into drought monitoring tools, serving policy and decisionmakers with timely information on drought conditions.

One of the best-known drought monitoring systems is the US Drought Monitor (USDM), ${ }^{1}$ which provides information about droughts in the USA since 1995 (Svoboda et al. 2002). The USDM has inspired several other regional drought monitoring systems, including the North American Drought Monitor $^{2}$ (Lawrimore et al. 2002) covering the USA, Canada and Mexico; the European Drought Observatory (EDO) $;^{3}$ and the African Flood and Drought Monitor (Sheffield et al. 2013).

Additionally, global drought monitoring systems exist, including the Global Drought Observatory ${ }^{4}$ developed by the EDO team, the Global Integrated Drought Monitoring and Prediction System by Hao et al. (2014) and the well-known SPEI Global Drought Monitor ${ }^{5}$ (Vicente-Serrano et al. 2012). The temporal resolutions of available drought monitoring systems typically range from daily to monthly observations, while the spatial resolutions range from kilometres to hundreds of kilometres. The frequency and resolution of national systems are generally higher than those operated at continental or global scales.

The available drought monitoring systems diagnose droughts in a given area in various ways. For example, the German Drought Monitor (Zink et al. 2016) relies on a hydrological model driven by meteorological observations to estimate daily soil moisture fields, which are then transformed into a soil moisture index, on the basis of which several drought severity classes are defined. Others use standard meteorological drought indices. The USDM uses the convergence of evidence approach, which combines weather- and satellite-based information with expert knowledge on drought impacts and selected key indicators into a single map.

In this review, we aim to provide an overview, assessment and analysis of the main scientific challenges, knowledge gaps and scientific problems with respect to drought monitoring in

\footnotetext{
$\overline{1}$ droughtmonitor.unl.edu

2 www.drought.gov/nadm/

3 edo.jrc.ec.europa.eu

${ }^{4}$ edo.jrc.ec.europa.eu/gdo/

${ }^{5}$ spei.csic.es/map/maps.html
}

the Pannonian Basin. The Pannonian Basin is a region in southeastern Europe in which agriculture plays a significant role for the national economies, e.g. for Hungary, Serbia, Bulgaria and Romania. However, it is expected that this region will be most negatively affected by droughts and heat waves in the future in terms of crop production (Olesen et al. 2011). Hence, drought monitoring is essential to adapt agricultural practices to changing weather and climate extremes.

The "Drought events and impacts in the Pannonian Basin" section covers a more detailed description of the Pannonian Basin (see the "Pannonian Basin" section), its recent drought events (see the "Recent drought events" section), and agricultural drought impacts (see the "Agricultural drought impacts" section). The "Drought monitoring efforts in the Pannonian Basin" section gives a brief overview of drought monitoring efforts in the Pannonian Basin. First, we present regional stakeholders and initiatives (see the "Regional stakeholders and initiatives" section) and then we present the established drought monitoring systems (see the "Established drought monitoring systems" section). In the "Earth Observation-based drought monitoring" section, we discuss the role of satellite-based variables in agricultural drought monitoring. Finally, in the "Future perspectivestowards integrated agricultural drought impact forecasting" section, we aim to provide future perspectives on how information from EO satellites can be used in combination with novel machine learning methods to forecast drought impacts on vegetation state and crop production.

\section{Drought events and impacts in the Pannonian Basin}

\section{Pannonian Basin}

The Pannonian Basin is a lowland area in southeastern Europe. It largely covers the centre of the Danube River Basin and is confined by the Alps in the west; the Bohemian-Moravian Highlands in the northwest; the Carpathians in the north, east and southeast; and by the Dinaric Alps in the southwest (Balázs et al. 2016) (Fig. 2). The Pannonian Basin has a warm-temperate climate (mean annual temperature: $10.5^{\circ} \mathrm{C}$ ) with warm summers and relatively cold winters and receives relatively low levels of precipitation (around $550 \mathrm{~mm}$ per year, the spatial variability is fairly homogenous, based on E-OBS v19.0e data (Cornes et al. 2018) for the period 1950-2018). Most precipitation falls from May to July, whereas January, February and March are the months with the least precipitation (Fig. 2). The Pannonian Basin is one of the largest agricultural regions in Europe, with cropland covering around $71 \%$ of the basin (Fig. 2).

The Pannonian Basin is being increasingly confronted with heat waves and droughts (Croitoru et al. 2016; Spinoni et al. 2017; Ceglar et al. 2018). The frequency and intensity of both 


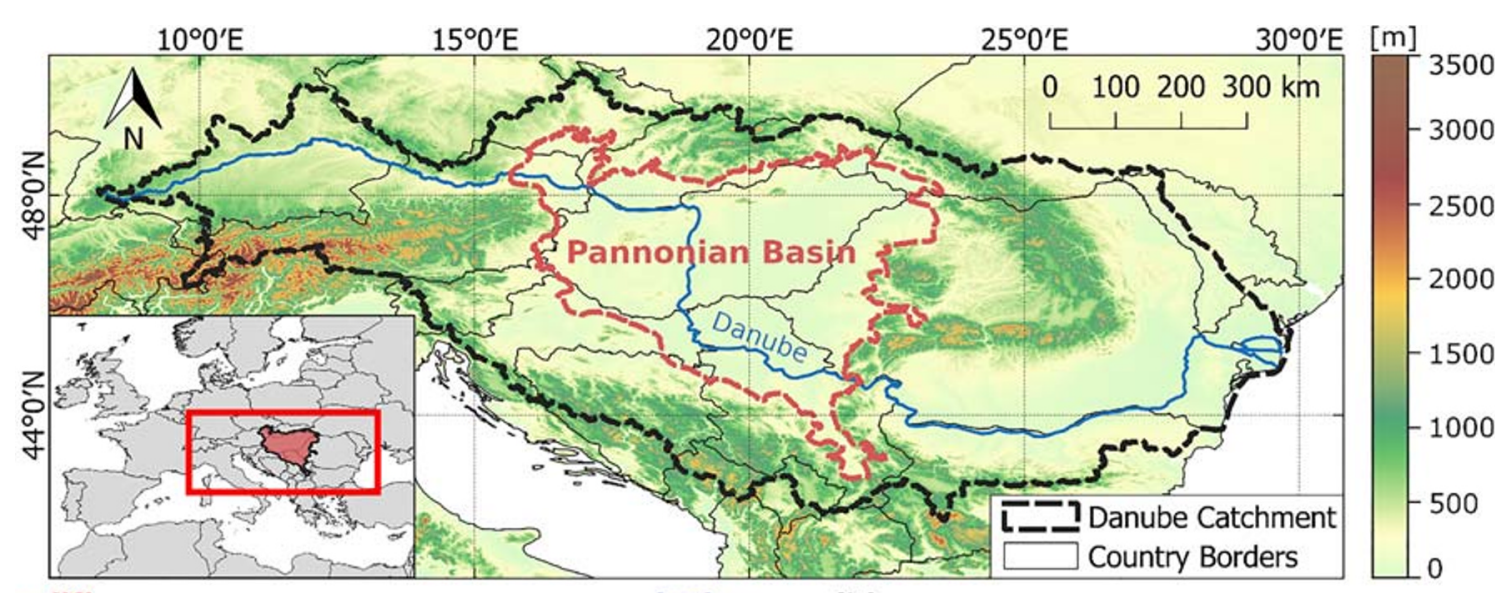

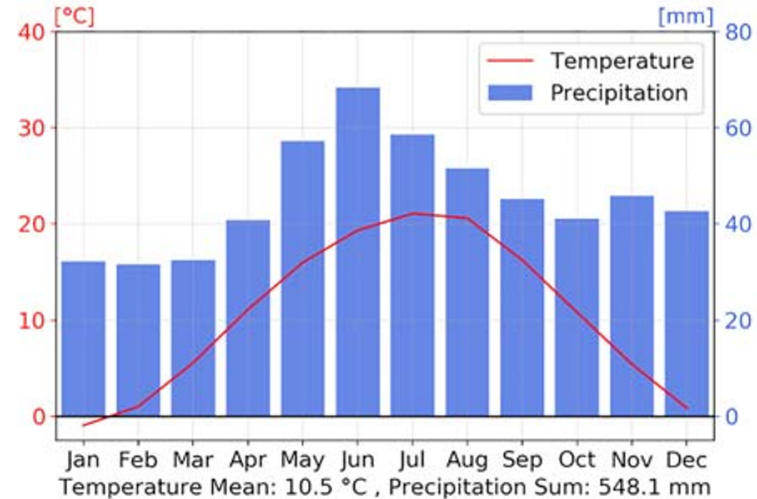

Fig. 2 Topography of the Danube Catchment and the Pannonian Basin. The boundaries of the Pannonian Basin are a combination of the definition of the biogeographical regions for Europe (2016) by the European Environment Agency (EEA 2016) and the definition of the European Environmental Stratification (Metzger 2018) (top). Climate of the Pannonian Basin for the period 1950-2018 based on E-OBS v19.0e

and their compound effects are expected to further increase due to climate change (Trnka et al. 2014, 2015; ICPDR 2015). Olesen et al. (2011) states that the Pannonian Basin is one of the regions that will be most severely affected in the future in terms of crop production, without possibilities for effectively shifting crop cultivation to other parts of the year. This is likely to have far-reaching impacts on agriculture, and thus on the regional economy.

\section{Recent drought events}

The Pannonian Basin and its surrounding area have suffered from multiple drought events of varying severity over the last decades (Fig. 3) (Spinoni et al. 2015; Ceglar et al. 2018). Examples are the frequent drought events that affected Hungary, Romania and Serbia during the period from 1983 to 1995 (Spinoni et al. 2013) and the long drought period in Romania between 2000 and 2003 (Kozak et al. 2011).

Spinoni et al. (2013) performed a detailed study of drought events that occurred between the years 1961 and 2010 in the Carpathian Region. They compared four drought indicators, where one is typically associated with meteorological

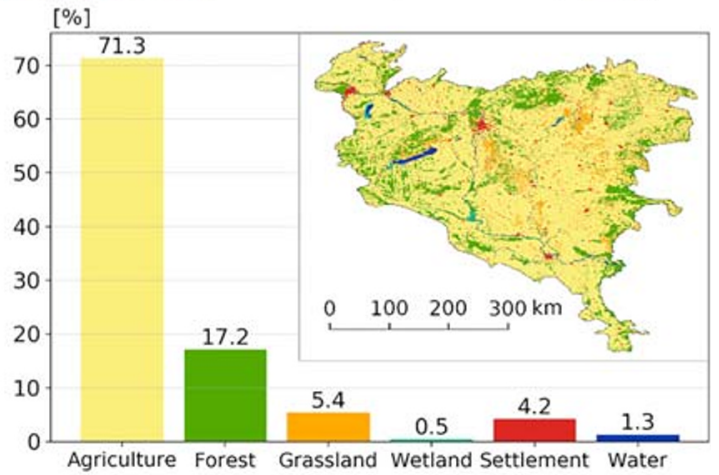

data (Cornes et al. 2018) (bottom left). Percentage of land cover for the Pannonian Basin for the year 2015 based on the ESA CCI land cover map (version 2.0.7) (ESA 2017). The classes in the bar chart correspond to the Intergovernmental Panel on Climate Change (IPCC) land categories used for change detection (bottom right)

droughts and three are typically associated with agricultural droughts. Four drought events occurred in the 2000s, three events were detected in the 60s, and two in the 1970s, 1980s and 1990s. Of the 13 observed droughts, three were considered exceptional: in 1990, 2000 and 2003. The 1990 drought was intense, especially in February, March and autumn. It was the longest drought event that occurred in this region in recent history. The drought in 2000 hit the entire Pannonian Basin and was the most intense one. The main driver was the rainfall deficit, but also the temperatures in the second half of 2000 were higher than the normal values (Spinoni et al. 2013). The event was particularly severe in Romania, where it was responsible for economic losses of over 500 million dollars (EM-DAT, the International Disasters Database). The year 2003 was extremely dry over the entire Europe. The lack of summer precipitation and extremely high temperatures were the main drivers for this exceptional drought which affected many sectors and caused enormous damage in agriculture, especially in Central and Eastern Europe (Rebetez et al. 2006).

The most recent agricultural drought events occurred in 2012 (Fiala et al. 2014; Zahradníček et al. 2015), 2015 (Van Lanen et al. 2016) and 2017 (Štěpánek et al. 2018). The 2012 
Fig. 3 Recent drought events in the Pannonian Basin. Years of exceptionally strong droughts are highlighted (top). Monthly precipitation/temperature based on E-OBS v19.0e data (Cornes et al. 2018) averaged over the Pannonian Basin for the exceptionally strong drought years in contrast to the mean precipitation/temperature over the years 1950-2018 (bottom)
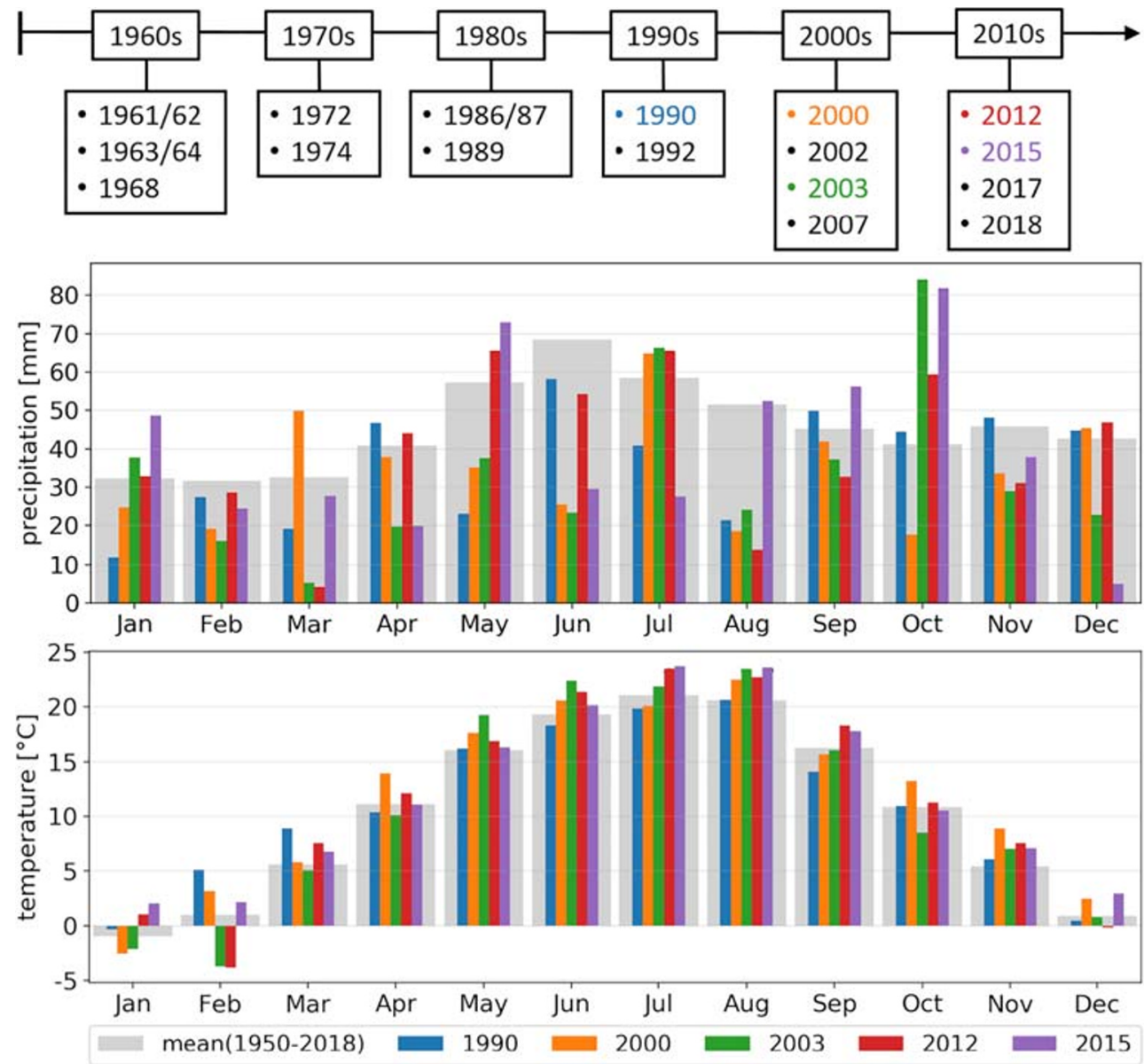

drought lasted from the beginning of June until the end of August (Govedarica et al. 2016). A lack of precipitation together with extremely high temperature in July and August were the main drivers of the severe drought. In 2015, a combination of rain shortages and very high temperatures led to major drought impacts across Austria, Bosnia and Herzegovina, Croatia, Czech Republic, Germany, Hungary, Moldova, Serbia, Slovakia, Slovenia and Ukraine (ICPDR 2015). The 2015 drought was severe particularly in Central and Eastern Europe (Van Lanen et al. 2016). In some regions, it was the driest (north of Slovakia) or second-driest (after the drought of 2003; Czech Republic and Poland) summer of the last 50 years. Severe droughts also affected most of the basins in 2017 and the northwest in 2018 (EDO 2018).

\section{Agricultural drought impacts}

According to the official agricultural yield statistics from Hungary, Romania, Slovakia and Serbia, in the years 2000, 2002, 2003, 2007 and 2012, droughts caused a loss in yield of 1 to $1.5 \mathrm{t} / \mathrm{ha}$ and $3 \mathrm{t} / \mathrm{ha}$ for wheat and maize, respectively, compared to the average yield of 2000-2015 (Nagy et al. 2018). This equates a yield loss of about $25-37.5 \%$ for winter wheat and over $40 \%$ for maize. According to Fiala et al.
(2014), maize is considered the most drought-sensitive crop cultivated in the Pannonian region, displaying a significant decrease of yield in dry years. The most significant droughtrelated decrease of maize yield in recent years was recorded in 2012, particularly in Hungary. In this year, maize yield was reduced by over $50 \%$ in the Csongrád county, while in the Bács-Kiskun county, it decreased by $44 \%$ compared to the average yield of the period 2000-2012 (based on data of the Hungarian Central Statistical Office). A similar situation occurred in Serbia with a 50\% decrease of maize yield, a $40 \%$ decrease of potato yield and a $25 \%$ decrease of sugar beet yield in comparison to the average yield from 2004 to 2018 (based on data of the Statistical Office of the Republic of Serbia). Vegetation stress caused by the drought in 2015 led to lower crop yields in many countries in Central and Eastern Europe. Crop losses of sugar beet and potatoes up to $50 \%$ were reported in the Czech Republic and Slovakia. A significant impact was also recorded on livestock farming because of lower hay harvest (loss about 50\% in the Czech Republic) and failing grass cuts (Slovakia), which led to substantial lower milk production in Slovakia and Romania (Van Lanen et al. 2016).

Jakubínský et al. (2019) created a comprehensive drought impact database for the Danube river catchment for the period 
Fig. 4 Number of reported drought impacts on agriculture (AGR), forestry (FOR), soil system (SOI), water resources (HYD) and impacts in the form of wildfires (WFR) for each year for all the available NUTS3 regions being part of the Pannonian Basin. The data were obtained from the drought impact database by Jakubínský et al. (2019)

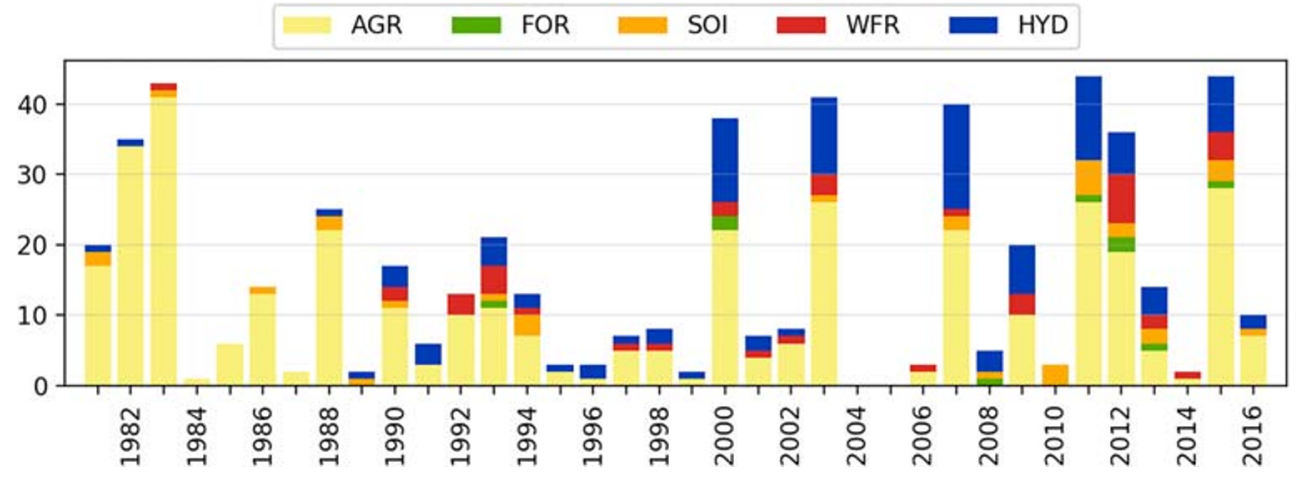

1981-2016 based on assessments of local newspapers and journal articles that reported drought impacts by regional drought experts. The individual drought impact reports were classified into five categories, depending on the sector in which the impacts of the drought episode were the most apparent: agriculture, forestry, soil system, wildfires and hydrology. In case of drought reports occurring in multiple categories over the same region and period, only one drought event is listed in the category of its highest impact. Whenever possible, the spatial distribution of the phenomena was categorised in Nomenclature of Units for Territorial Statistics level 3 (NUTS3) regions of the Member States of the European Union. In non-EU countries, national divisions were used with the area of each region roughly equivalent to the size of NUTS3 regions. Impacts affecting more than one NUTS3 region were counted separately for each region (Jakubínský et al. 2019).

Although the quality of the drought impact database is influenced by several factors, e.g. the different human perception of a drought event in different countries and inhomogeneous data sources, to date, this is the most complete and accurate database of reported drought events in the region.

The number of reported drought impacts from the drought impact database by Jakubínský et al. (2019) for the period from 1981 to 2016 is shown in Fig. 4. The drought impacts were summed up for all the NUTS3 regions being part of the Pannonian Basin where the data was available at the NUTS3 level (i.e. Croatia, Czech Republic, Hungary, Romania, Slovakia, Slovenia). It can be seen that there were numerous agricultural drought impacts in the years 1982, 1983, 1988, 2000, 2003, 2007, 2011, 2012 and 2015. Here, it must be mentioned that the high number of agricultural impacts (26) and hydrological impacts (12) in the year 2011 are mainly reported by Croatia ( 23 agricultural impacts and 8 hydrological impacts), (see Cindrić et al. (2016) for more details about the 2011 drought). However, since only a small part of Croatia belongs to the Pannonian Basin, literature investigating the Pannonian Basin often does not list this year as an extraordinary drought year.

\section{Drought monitoring efforts in the Pannonian Basin}

\section{Regional stakeholders and initiatives}

Several cooperative initiatives have been established to manage drought-related risks in the Pannonian Basin. The Drought Management Centre for South Eastern Europe (DMCSEE) $^{6}$ was established in 2006 by the hydrometeorological services of 14 countries in cooperation with the United Nations Convention to Combat Desertification and the World Meteorological Organisation (WMO). The mission of the DMCSEE is to coordinate and facilitate the development, assessment and application of drought risk management tools and policies in southeastern Europe with the goal of improving drought preparedness and reducing drought impacts. The Centre provides information on the drought situation in the region through monthly drought bulletins that are based on numerical weather prediction model simulations, SPI index calculations and remote sensing data.

The Integrated Drought Management Programme for Central and Eastern Europe (IDMP CEE) was launched by the WMO and the Global Water Partnership in February 2013. In Central and Eastern Europe, the programme involves more than 40 organisations representing ten countries, nine of which are from the Danube region. The IDMP CEE provides monitoring and early warning for droughts, assessments of vulnerabilities and drought impacts, and strategies for drought mitigation and preparedness (IDMP 2018).

The Pannonian Basin Experiment (PannEx), which is part of the Global Energy and Water Exchanges activity (Ceglar et al. 2018), reconciles user needs and state-of-the-art scientific knowledge in order to identify gaps in our hydroclimatological knowledge of the region. The main research priorities address current challenges in agriculture, air quality, sustainable development, water management and education (Ceglar et al. 2018). The European Space Agency (ESA) contributes to PannEx with its EO programme by initiating a

\footnotetext{
${ }^{6}$ www.dmcsee.org
} 
regional initiative for the Black Sea and Danube region. One of the priorities of this initiative is EO-based environmental monitoring, including drought characterisation for the Danube Basin.

\section{Established drought monitoring systems}

A regional high-resolution evidence-based monitoring and early warning system called Drought Watch ${ }^{7}$ was recently developed for the Pannonian Basin (Bucur et al. 2018). This system includes remotely sensed drought indicators of soil moisture and vegetation conditions. National reporting networks, consisting of farmers and other agricultural experts, have been set up to compile weekly drought impact maps. These maps provide information on how drought influences expected crop yield or forest growth at a specific location.

One of the most advanced drought monitoring systems for the region is the drought monitoring system for the Czech Republic and Slovakia called InterSucho, ${ }^{8}$ which is based on several independent approaches (Trnka et al. 2020). The system simulates the soil water balance with the SoilClim model (Hlavinka et al. 2011; Štěpánek et al. 2018) and covers the entire area of the Czech Republic and Slovakia with a spatial resolution of $500 \mathrm{~m}$. In addition, InterSucho reports soil moisture, evaporation and vegetation conditions from satellite observations for Central Europe and provides information on drought impacts. Moreover, the system provides a drought forecast based on numerical weather prediction for the upcoming 9 days and a weekly drought outlook for the upcoming 2 months based on statistical likelihood of drought with respect to the current state and typical weather pattern.

\section{Earth Observation-based drought monitoring}

The following subchapters are not restricted to the Pannonian Basin only but apply worldwide for agricultural drought monitoring.

\section{Satellite-based variables and their use in drought monitoring}

Many state-of-the-art drought monitoring systems (see the "Drought mechanisms" and "Established drought monitoring systems" sections) make use of satellite-based indicators, with demonstrable improvements in drought monitoring capabilities. Satellites can detect variables of meteorological drought such as precipitation and land surface temperature, of

\footnotetext{
7 droughtwatch.eu

8 intersucho.cz
}

agricultural drought such as soil moisture, vegetation state, land surface temperature and evapotranspiration, and of hydrological drought such lake extent, lake and river levels and terrestrial water storage (AghaKouchak et al. 2015; Zhang et al. 2016; West et al. 2019).

The most important EO technologies for agricultural drought monitoring, including frequently used satellite systems, derived surface variables and their advantages and limitation are listed in Table 1. In the following subchapters, we will give an overview of the key EO observables for agricultural drought monitoring, explain why they are important for agricultural drought monitoring, how they can be measured via remote sensing and how they are used in drought monitoring.

Often these variables are not used directly. Instead, anomalies are derived from the variables as drought indicators or they serve as input for drought indices. It must be noted that in literature, often there is no distinction between the terms "drought indicator" and "drought indices" and both terms are used interchangeably. In this work, the term "drought indicator" is used when referring to a physical characteristic of a specific variable (e.g. soil moisture anomalies), while the term "drought index" is used when referring to a numerical representation of a drought's severity or magnitude (e.g. Soil Water Deficit Index (SWDI) (Martínez-Fernández et al. 2015)).

\section{Soil moisture}

Reliable, accurate and timely information about the actual and historic water content of soils is crucial to establishing an effective drought monitoring and prediction system. Soil moisture (SM) anomalies are a good indicator to detect agricultural drought events and several drought indices use SM as their input (Sridhar et al. 2008; Martínez-Fernández et al. 2015; Sohrabi et al. 2015; Sánchez et al. 2016; Carrão et al. 2016; Yang et al. 2017; Xu et al. 2018).

Based on the wavelength of the observed electromagnetic radiation, three different general approaches for retrieving SM from satellite data exist: optical, thermal infrared and microwave remote sensing. Optical and thermal infrared remote sensing methods have some limitations concerning the retrieval of soil moisture, e.g. due to the limited penetration of sunlight through the vegetation canopy or variation across time and land cover types due to a strong dependence on local meteorological conditions (e.g. high cloud cover). The most effective technique for space-borne SM estimation is microwave remote sensing (Wardlow et al. 2012). Several operational global products are generated from active as well as passive microwave data. Operational satellite SM products are derived from the Soil Moisture Active Passive (SMAP) mission (Entekhabi et al. 2010), the Soil Moisture Ocean Salinity (SMOS) mission (Kerr et al. 2010), the Advanced Scatterometer (ASCAT) (Bartalis et al. 2007), or the 
Advanced Microwave Scanning Radiometer 2 (AMSR2) (Jackson et al. 2010), as well as the ESA Climate Change Initiative (CCI) and Copernicus Climate Change Service (C3S) SM products (Gruber et al. 2017, 2019; Dorigo et al. 2017). However, these products have a spatial resolution that is rather coarse $(9-40 \mathrm{~km})$, which limits their usability for small-scale drought monitoring. However, novel methods to downscale the existing SM estimates to finer resolutions make them increasingly interesting for regional drought monitoring, e.g. in the Pannonian Basin. The SCATSAR Soil Water Index (SWI) product distributed through the Copernicus Global Land Service (CGLS) is one example combining highresolution Sentinel-1 data with long-term but coarse resolution ASCAT data to provide estimates of the soil water content at an unprecedented combination of spatial $(1 \mathrm{~km})$ and temporal (1 day) resolution (Bauer-Marschallinger et al. 2018).

Satellite SM products have great potential for agricultural drought monitoring. Cammalleri et al. (2017) found that remote sensing datasets are particularly suitable for drought monitoring, especially, over dry areas and sparsely monitored areas. In the studies by Martínez-Fernández et al. (2016, 2017), data from the SMOS and the CCI SM product were used to derive the SWDI, while Mishra et al. (2017) and Zhu et al. (2019) used SMAP data to derive the SWDI.

\section{Vegetation state}

In most cases, agricultural drought affects vegetation in terms of decreased production, increased plant mortality, poor vegetation health and lower yields. Vegetation variables and vegetation indices (spectral transformations of two or more bands designed to enhance the vegetation signal) (Huete et al. 2002) obtained via remote sensing can be valuable for identifying plant stress due to drought and can be used in crop management to maximise production (Dorigo et al. 2007). Seasonal integrals of vegetation indicators are good proxies for the total Gross Primary Productivity (GPP) or Net Primary Productivity (NPP) that together with a harvest index can be related to the potential yield (Johnson 2016; He et al. 2018) and are, therefore, important measures for yield estimation.

Traditionally, remote sensing of vegetation state measures electromagnetic wave reflectance information from canopies in the wavelength range between 400 and $2500 \mathrm{~nm}$ (Xue and $\mathrm{Su}$ 2017). The reflectance in these bands provides information among others on greenness, relative density, chlorophyll content, leaf water content and health of vegetation. Well-known vegetation variables that can be derived from these observations are the fraction of absorbed photosynthetically active radiation (fAPAR), Leaf Area Index (LAI) and Gross Primary Productivity (GPP), while examples of vegetation indices are the Normalized Difference Vegetation Index (NDVI) (Tucker 1979) or the two-band Enhanced Vegetation Index (EVI2) (Jiang et al. 2008). Newer 
approaches of vegetation remote sensing make use of high spectral-resolution observations in the red/near-infrared domain to derive Sun-Induced chlorophyll Fluorescence (SIF) or of space-borne microwave observations to derive Vegetation Optical Depth (VOD). SIF is a measure for photosynthetic activity that provides an estimate for the amount of carbon that is taken up by plants based on the re-emission of sunlight (Mohammed et al. 2019). VOD is an indicator for vegetation density, biomass and water content (Konings et al. 2019) and is also related to GPP (Teubner et al. 2019).

All these variables and indices have already been used for drought monitoring and to identify losses in the agricultural sector. A study by Nagy et al. (2018) tested MODIS NDVI for estimating wheat and maize yield losses affected by drought in the Tisza river catchment. Rossi et al. (2008) showed that fAPAR is able to capture droughts by evaluating its performance by correlating fAPAR anomalies with the anomalies of independent other drought indicators, i.e. the SPI, soil moisture anomalies and surface temperature anomalies. Chen et al. (2019) explored the potential of satellite-borne SIF in drought detection and crop production assessment and demonstrated that SIF is reliable for drought monitoring.

\section{Land surface temperature}

Land surface temperature (LST) is a fundamental parameter in the physics of surface energy and water balance. It serves as proxy for assessing evapotranspiration, vegetation water stress, soil moisture and thermal inertia (Karnieli et al. 2010). LST is derived from thermal infrared or microwave satellite observations (Holmes et al. 2015), where thermal radiance from the land surface is converted to a radiometric temperature associated with the Earth's skin (Hulley et al. 2019). Since high LSTs can be associated with moisture deficit in soil and vegetation, LST is recognised as a drought indicator either on its own or in combination with a vegetation indicator like NDVI (Kogan 1995, 2000; Orhan et al. 2014).

LST and NDVI are typically strongly negatively correlated (Goward et al. 1985; Hope and McDowell 1992). Many studies make use of this relationship with respect to drought monitoring (Karnieli et al. 2010). McVicar and Bierwirth (2001) assessed drought by computing the ratio of LST and NDVI. A study by Hu et al. (2019) computed the vegetation temperature condition index for agricultural drought monitoring, based on LST and radiance products of Sentinel-3A SLSTR (sea and land surface temperature radiometer).

\section{Evapotranspiration}

Evapotranspiration (ET) is a key variable of the landscape water balance. It describes the exchange of water between the land surface including plants and the atmosphere and is, therefore, a measure of water loss. The controls on ET include temperature, radiation, wind speed and relative humidity (McVicar et al. 2012; Seneviratne 2012). All these drivers affect the conductance of stomata, canopy and the surface and are represented in physical-based evapotranspiration models such as the Penman-Monteith formulation (Allen et al. 1998). ET can be used to describe the water availability, but also the water consumption rate of plants and is, therefore, a viable indicator of vegetation health and a useful variable for drought monitoring (Zhang et al. 2019).

ET can be modelled or estimated indirectly through satellite remote sensing (Zhang et al. 2016). Examples of the latter are the MODIS Global Terrestrial Evapotranspiration Product ( $\mathrm{Mu}$ et al. 2013) and the Global Land Evaporation Amsterdam Model (GLEAM) (Miralles et al. 2011, 2014; Martens et al. 2017). GLEAM uses a set of algorithms to estimate the different components of evaporation from remotely sensed input variables (e.g. precipitation, radiance, vegetation optical depth). Other EO methods for determining ET are generally either based on an empirical relationship between ET, crop coefficient (or surface resistance) and some vegetation metric or use an energy balance approach (Anderson et al. 1997; Allen et al. 2011). As an example of the latter, the Atmosphere-Land Exchange Inverse (ALEXI) model (Anderson et al. 1997, 2007) combines the two-source energy balance method, where the fluxes from soil and vegetation are treated separately (Norman et al. 1995), with a simple atmospheric boundary layer model. This diagnostic model is based on satellite retrievals of LST combined with additional data of meteorological conditions including solar radiation and information about the surface properties such as LAI or canopy height. The basic principle of the ALEXI model is to quantify how much water loss is required to keep the soil and vegetation at the observed temperatures under given known radiative energy inputs.

Several drought indices use ET as input (Mu et al. 2012; Kim and Rhee 2016; Hobbins et al. 2016; Zhang et al. 2019). One example is the Evaporative Stress Index (ESI) (Anderson et al. 2011, 2013), which is based on ALEXI. The ESI represents the ratio of actual to reference ET standardised anomaly and is available with a weekly temporal resolution in the form of two composites with $0.05^{\circ}$ spatial resolution: a 4 -week composite with the ability to capture flash drought events and a 12-week composite with a potential to indicate agricultural as well as hydrological drought. The ESI is routinely used in the InterSucho portal alongside the SWI to assess water stress across Central Europe. Anderson et al. (2016) investigated the relationship between ESI and winter wheat and spring barley yields in the Czech Republic. Drought years characteristic of large yield losses were captured by negative anomalies in the ESI. 


\section{Comparison of drought indicators and drought indices over the Pannonian Basin}

Several commonly used remote sensing-based drought indicators and drought indices for the Pannonian Basin are shown in Figs. 5 and 6. Several studies showed that these indicators and indices can be used for agricultural drought monitoring and yield prediction (Anderson et al. 2016; Mathieu and Aires 2018a, b; Chaparro et al. 2018; Nagy et al. 2018; Chen et al. 2019). The temporal variability is visualised with Hovmöller diagrams. Water-related drought indicators/indices are shown in Fig. 5: SPEI is based on precipitation and temperature data and can be computed at different time scales. The ESI can detect water stress based on ET, while the SWI provides an estimate of the moisture content in the soil profile.

Vegetation-based drought indicators such as NDVI, VOD and SIF anomalies are shown in Fig. 6.

Comparing the patterns in these two plots, we see strong correspondence between soil moisture and vegetation indicators/indices as well as the drought events discussed in the "Recent drought events" section and drought impacts discussed in the "Agricultural drought impacts" section. The right-hand column in Figs. 5 and 6 depict the spatial distribution of indicators/indices associated with a severe drought event during September 2012. When comparing the maps of Figs. 5 and 6 , it is obvious that the negative anomalies of water-related drought indicators/indices correlate with the negative anomalies of vegetation-based drought indicators.

\section{Future perspectives-towards integrated agricultural drought impact forecasting}

A key interest of the agricultural sector is to receive information on how drought impacts soil moisture conditions, plant productivity, biomass production and hence agricultural yields. Such information will potentially help to adapt irrigation and land management strategies and hence to mitigate drought impacts, not only in the Pannonian Basin but also worldwide. As discussed in the "Earth Observation-based drought monitoring" section, satellite-based variables are increasingly used for drought monitoring and yield impact prediction due to their advantage of being globally available. More and more studies using new machine learning methods to predict yields and drought impacts are being carried out, but they are still in their infancy.

\section{Complementarity of information sources}

Due to the increasing availability of sophisticated, operational EO data, meteorological forecasts and (agro-)ecosystem model improvements, significant progress has been made towards the assessment of drought impacts on agro-ecosystem functioning and yield forecasting. However, the combination of these data sources remains nearly untouched, despite their complementary potential. The new fleet of Sentinel and commercial EO satellites provides systematic updates on soil moisture and vegetation conditions every few days at high spatial resolutions down to a few meters. Meanwhile, new long-term climate data records provide a systematic and consistent baseline of past land surface conditions over the last 40 years but at lower spatial resolutions (Dorigo et al. 2017). These new products are complemented with new observables of ecosystem functioning, e.g. SIF, GPP or vegetation water content (Sun et al. 2018; Moesinger et al. 2019a; Teubner et al. 2019).

Seasonal meteorological forecasts have improved and are able to provide skilful estimates of the key drivers of drought up to several months ahead (Johnson et al. 2019), which in turn can be used to compute classical drought indices like SPI or SPEI, or to drive land surface models that simulate soil moisture anomalies and vegetation impacts.

Despite their lower actual spatial resolution than current EO data (e.g. because of the absence of forcing and ancillary data at these scales), process-based (agro-)ecosystem models allow for a better mechanistic understanding of the impact of droughts on crop development and provide seamless estimates in space and time. Hence, they can be used in predictive mode by including seasonal forecasts of meteorological variables.

\section{Integrating multiple data streams}

Integrating the various data sources and approaches for improved drought impact forecasting can evolve along various pathways and at various stages in the drought information system. The approaches to do so can roughly be categorised into machine learning approaches and model-data integration techniques (Fig. 7).

Machine Learning (ML) can be used to:

- Establish the most suitable drought impact diagnostic: ML allows identifying the observable diagnostics that are most sensitive to climate anomalies and indicative for yield anomalies. These diagnostics can then be targeted for by drought (impact) forecast models.

- Identify the key drivers of agricultural drought and their impacts on yield: ML is able to simultaneously assess the importance of multiple, co-varying drivers. Actually, thousands of features can be ingested simultaneously in ML models (Papagiannopoulou et al. 2017) or emergent features can be obtained from deep learning models (Reichstein et al. 2019).

- Predict drought diagnostics: Based on current and past observed states, e.g. of soil moisture, precipitation, or vegetation conditions and their cumulative memory effects, ML can be used to predict future states of these variables. 
Fig. 5 Temporal variability of three drought indicators/indices averaged over the Pannonian Basin: SPEI-3 computed at the time scale of 3 months from the ERA5 reanalysis; the 12-week composite of ESI; and the SWI anomalies $(T$ value $=40)$ based on the $0.1^{\circ}$ product distributed through the CGLS. The righthand side shows the spatial distribution of these variables for a drought in September 2012 throughout the Pannonian Basin. The colours of the maps are equivalent to the colours of the corresponding Hovmöller diagram

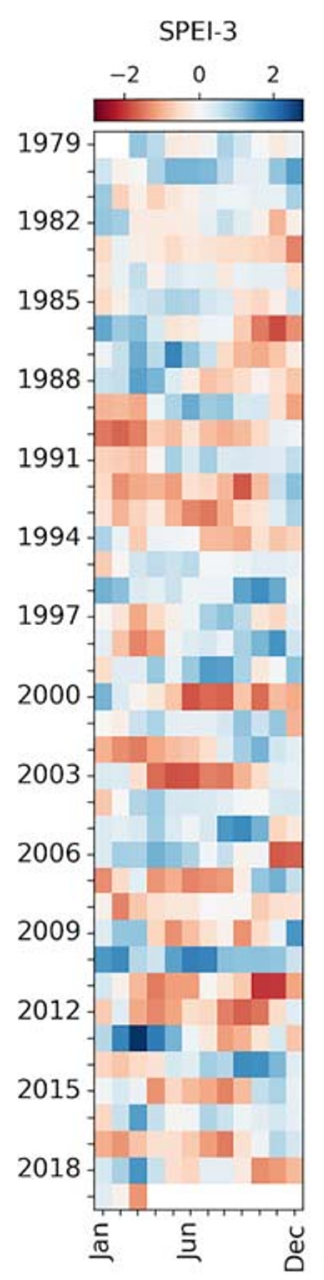

SWI anomalies
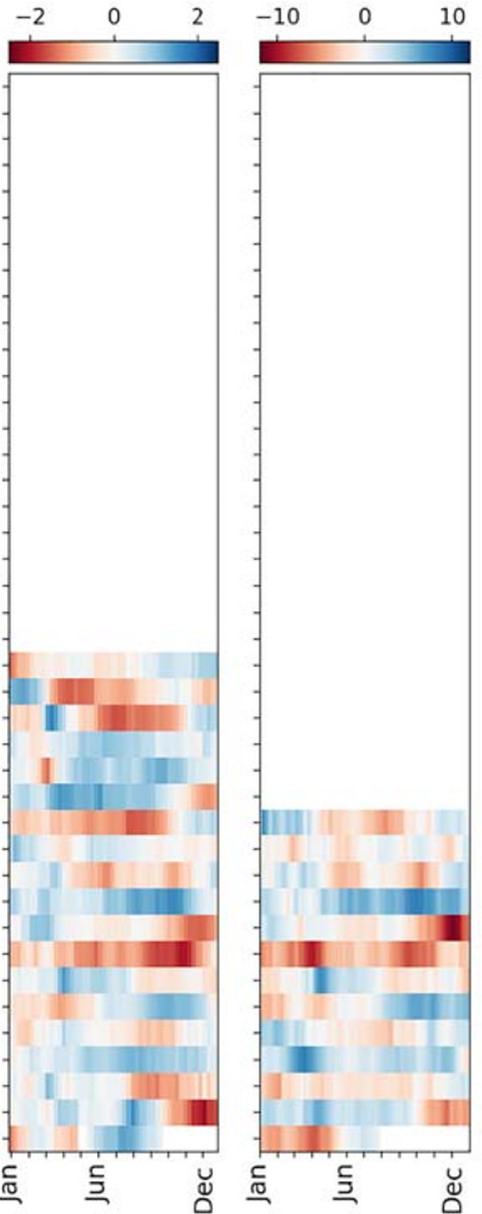

September 2012

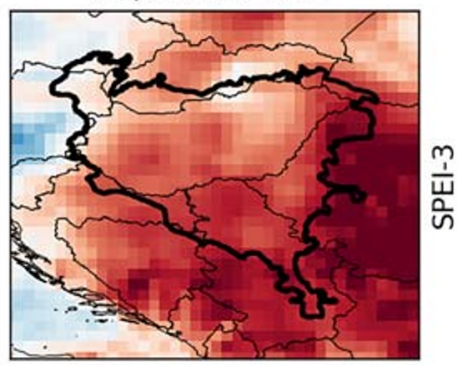

$\frac{m}{\frac{1}{\omega}}$
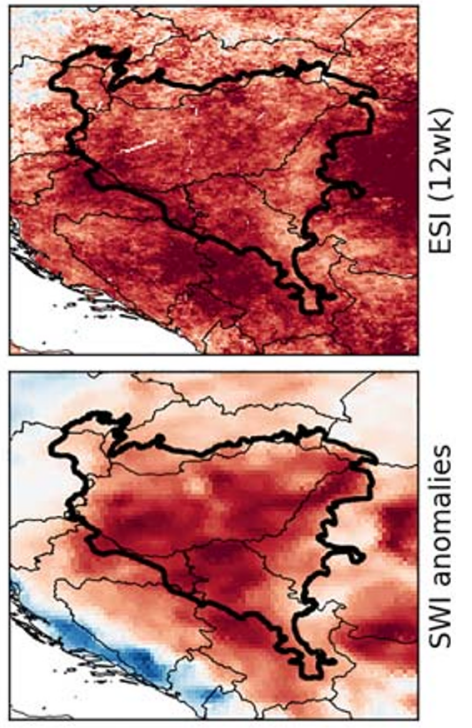

These predicted states can then be used alone or in combination with process-based forecasts to drive processbased crop and yield models.

Integration of EO with land surface models can be used to combine multiple data streams, e.g. by:

- Benchmarking model physics: The emergent relationships between meteorological drivers, droughts and drought impacts identified by ML from the observational data cubes may be insufficiently accounted for by the land surface and vegetation models used for prediction. Hence, observation-based relationships provide a unique opportunity to identify and improve the model processes (Forkel et al. 2019).

- Calibrating model parameters: Constraining land surface model states like soil moisture by observed values allows to optimise model parameters, e.g. those controlling the response of evapotranspiration and photosynthesis to drought. Particularly the increasing availability of novel EO data sets allows initial calibration of global land surface models to local and regional conditions (Drüke et al.
2019). A proper model calibration should assess the change in performance of the agro-ecosystem model, in particular with respect to extreme events (droughts) (Huang et al. 2019). In addition, novel climate ensembles allow estimating probabilities and recurrence times of drought impacts on ecosystems (Sippel et al. 2017).

- Updating initial and intermediate conditions in land surface, vegetation and yield models (i.e. data assimilation) with observed values continuously improves the predicted vegetation and yield anomalies (Albergel et al. 2019).

- Optimally combining data-driven and process-based forecasts of drought and drought impact variables by generating weighted averages of the multiple datasets based on their respective error characteristics.

- Hybrid approaches combining model forecasts with observations. For example, one could use the best surface soil moisture forecast, based on a combined meteorological/ land surface model forecast, with the best ML approach for linking surface soil moisture to yield.

With the wealth of new EO datasets and advances in using $\mathrm{ML}$ for EO, a solid foundation is being laid for improving 
Fig. 6 Temporal variability of three drought indicators averaged over the Pannonian Basin: NDVI anomalies based on the 1-km product distributed through the CGLS; SIF anomalies based on retrievals from GOME-2 on MetOp-A (Joiner et al. 2013, 2014, 2016); and VOD anomalies based on the VODCA X-Band product (Moesinger et al. 2019b). The right-hand side shows the spatial distribution of these variables for a drought in September 2012 throughout the Pannonian Basin. The colours of the maps are equivalent to the colours of the corresponding Hovmöller diagram
NDVI anomalies

$\begin{array}{lll}-0.15 & 0.00 & 0.15\end{array}$

2000

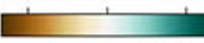

anomalies

$\begin{array}{lll}-0.1 & 0.0 & 0.1\end{array}$
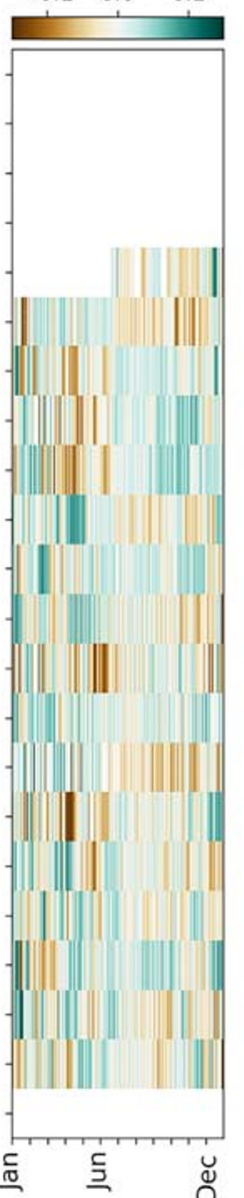

2006

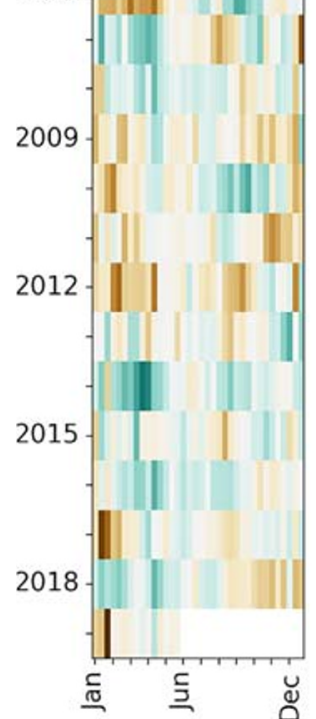

SIF anomalies
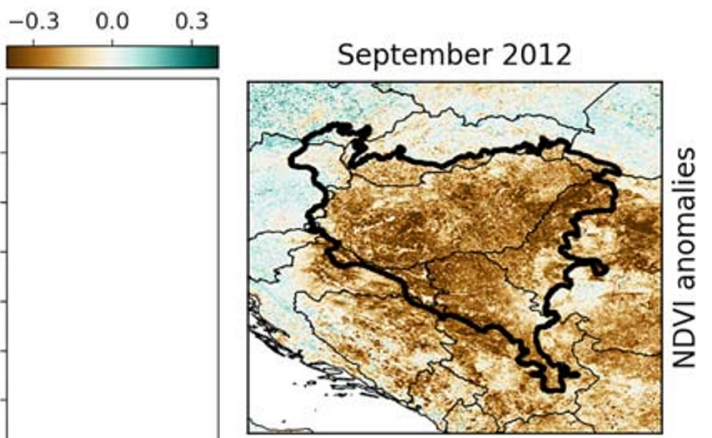

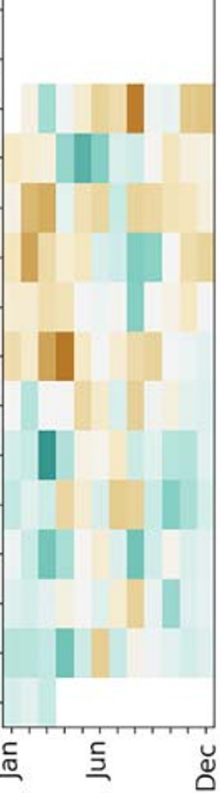

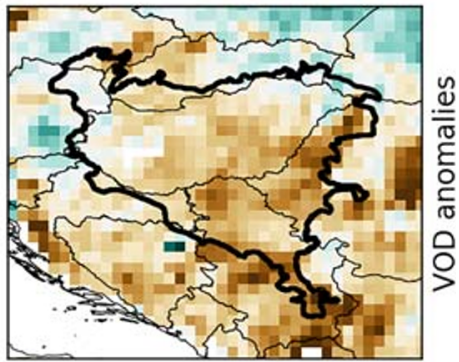

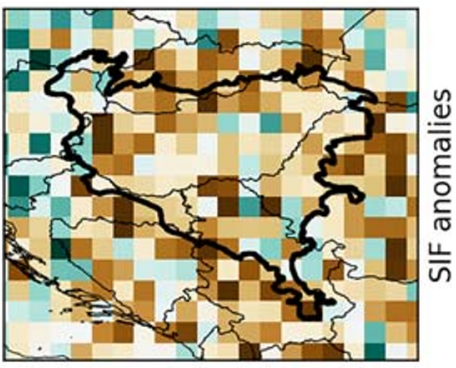

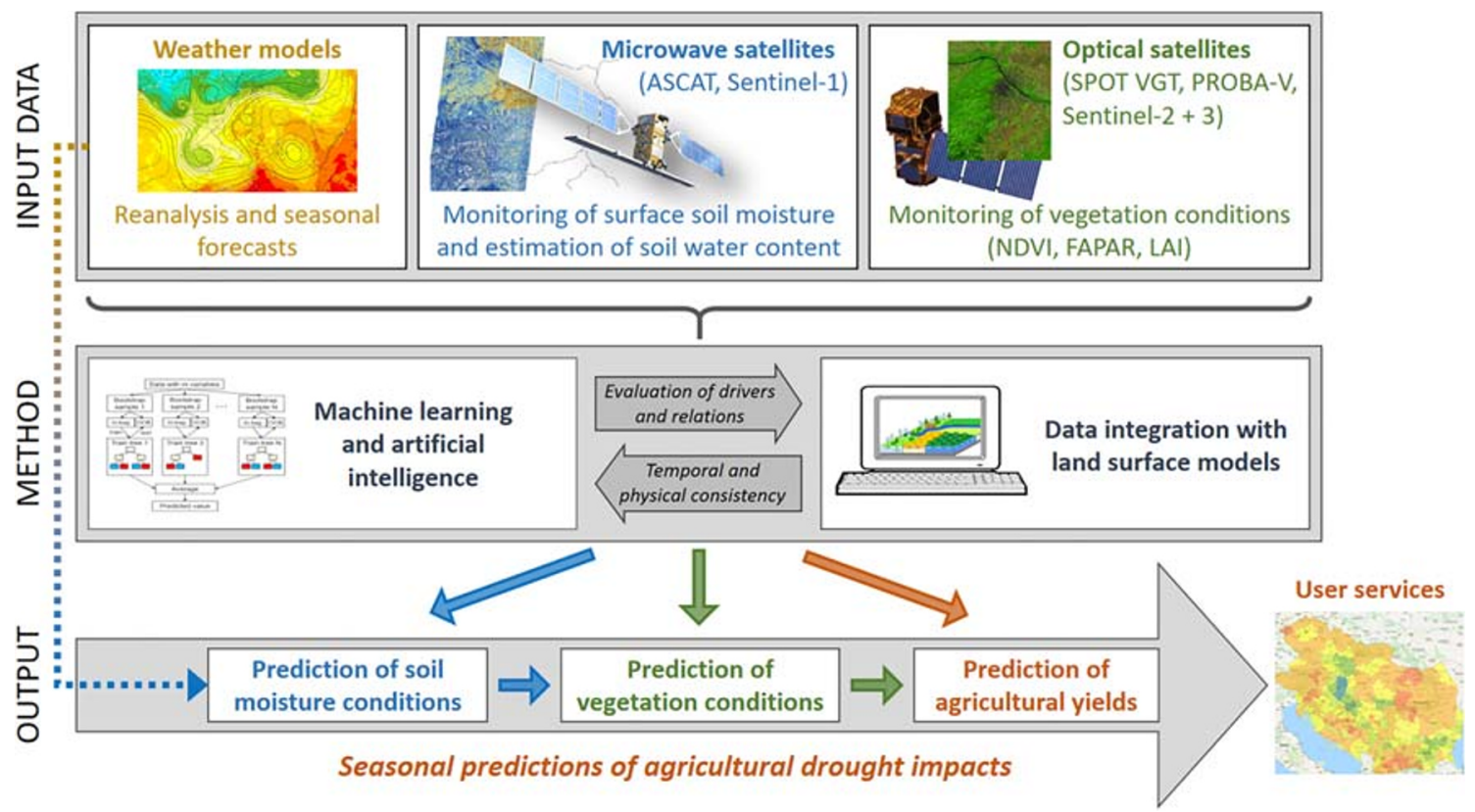

Fig. 7 Conceptual outline to integrate meteorological reanalysis and seasonal forecasts with optical and microwave satellite observations within machine learning approaches and land surface models to enable seasonal predictions of agricultural drought 
drought monitoring and (impact) forecasting systems. ESA's upcoming Earth Explorer - Fluorescence Explorer mission, scheduled to be launched in mid-2024, will provide global measurements of vegetation fluorescence to quantify photosynthetic activity, plant health and stress. The mission will help to understand how photosynthesis affects the carbon and water cycle. This information is valuable since understanding plant health and productivity is essential to predict drought impacts on vegetation.

\section{Conclusions}

Recent drought events in the Pannonian Basin have created an urgent need for advanced monitoring of drought (impacts) on agriculture by international programmes and regional practitioners. In addition to meteorological reanalysis and forecast data, EO estimates of surface soil moisture, evapotranspiration and vegetation conditions are already included in operational drought monitoring portals such as droughtwatch.eu and intersucho.cz that provide up-to-date information on drought conditions in the Pannonian Basin and neighbouring regions. However, forecasts of drought impacts on vegetation and agricultural productivity, including an umbrella of methods from classical crop growth and land surface modelling, statistical correlation and regression analyses, machine learning and artificial intelligence are still in their infancy. A systematic assessment of the predictive performance of forecasting approaches using different EO variables and methods is still lacking. For the Pannonian Basin area, user-oriented drought monitoring portals are already in place and capable of providing forecasts of drought impacts to practitioners, but the scientific development and assessment for such forecasts is missing.

Funding Open access funding provided by TU Wien (TUW). This research was mainly supported by the DryPan project funded by the European Space Agency (4000127214/19/I-EF) and the TU Wien Wissenschaftspreis 2015, awarded to Wouter Dorigo. The work by Milan Fischer, František Jurečka and Miroslav Trnka was partly conducted with support of project SustES - Adaptation strategies for sustainable ecosystem services and food security under adverse environmental conditions (CZ.02.1.01/0.0/0.0/16_019/0000797). The work by Aleš Grlj and Žiga Kokalj was partly funded by the Slovenian Research Agency core funding No. P2-0406, and by research project No. J6-9395. The authors also received from the TU Wien Bibliothek financial support through its Open Access Funding Programme.

Open Access This article is licensed under a Creative Commons Attribution 4.0 International License, which permits use, sharing, adaptation, distribution and reproduction in any medium or format, as long as you give appropriate credit to the original author(s) and the source, provide a link to the Creative Commons licence, and indicate if changes were made. The images or other third party material in this article are included in the article's Creative Commons licence, unless indicated otherwise in a credit line to the material. If material is not included in the article's Creative Commons licence and your intended use is not permitted by statutory regulation or exceeds the permitted use, you will need to obtain permission directly from the copyright holder. To view a copy of this licence, visit http://creativecommons.org/licenses/by/4.0/.

\section{References}

AghaKouchak A, Farahmand A, Melton FS, Teixeira J, Anderson MC, et al (2015) Remote sensing of drought: progress, challenges and opportunities. Rev Geophys 53:452-480. https://doi.org/10.1002/ 2014RG000456

Albergel C, Dutra E, Bonan B, Zheng Y, Munier S et al (2019) Monitoring and forecasting the impact of the 2018 summer heatwave on vegetation. Remote Sens 11:520. https://doi.org/10. 3390/rs11050520

Allen R, Irmak A, Trezza R, Hendrickx JMH, Bastiaanssen W et al (2011) Satellite-based ET estimation in agriculture using SEBAL and METRIC. Hydrol Process 25:4011-4027. https://doi.org/10. 1002/hyp.8408

Allen RG, Pereira LS, Raes D, Smith M (1998) Crop evapotranspiration guidelines for computing crop water requirements - FAO irrigation and drainage paper 56. Food and Agriculture Organization of the United Nations, Rome

Anderson MC, Hain C, Otkin J, Zhan X, Mo K et al (2013) An Intercomparison of drought indicators based on thermal remote sensing and NLDAS-2 simulations with U.S. drought monitor classifications. J Hydrometeorol 14:1035-1056. https://doi.org/10. 1175/JHM-D-12-0140.1

Anderson MC, Hain C, Wardlow B, Pimstein A, Mecikalski JR et al (2011) Evaluation of drought indices based on thermal remote sensing of evapotranspiration over the continental United States. J Clim 24:2025-2044. https://doi.org/10.1175/2010JCLI3812.1

Anderson MC, Hain CR, Jurecka F, Trnka M, Hlavinka P et al (2016) Relationships between the evaporative stress index and winter wheat and spring barley yield anomalies in the Czech Republic. Clim Res 70:215-230. https://doi.org/10.3354/cr01411

Anderson MC, Norman JM, Diak GR, Kustas WP, Mecikalski JR (1997) A two-source time-integrated model for estimating surface fluxes using thermal infrared remote sensing. Remote Sens Environ 60: 195-216. https://doi.org/10.1016/S0034-4257(96)00215-5

Anderson MC, Norman JM, Mecikalski JR, Otkin JA, Kustas WP (2007) A climatological study of evapotranspiration and moisture stress across the continental United States based on thermal remote sensing: 1. Model formulation. J Geophys Res Atmos 112:. https://doi. org 1 10.1029/2006JD007506

Balázs A, Matenco L, Magyar I, Horváth F, Cloetingh S (2016) The link between tectonics and sedimentation in back-arc basins: new genetic constraints from the analysis of the Pannonian Basin. Tectonics 35: 1526-1559. https://doi.org/10.1002/2015TC004109

Bartalis Z, Wagner W, Naeimi V, Hasenauer S, Scipal K, et al (2007) Initial soil moisture retrievals from the METOP-A Advanced Scatterometer (ASCAT). Geophys Res Lett 34. https://doi.org/10. 1029/2007GL031088

Bauer-Marschallinger B, Paulik C, Hochstöger S, Mistelbauer T, Modanesi S et al (2018) Soil moisture from fusion of scatterometer and SAR: closing the scale gap with temporal filtering. Remote Sens 10:1030. https://doi.org/10.3390/rs10071030

Bucur A, Gregorič G, Grlj A, Kokalj Ž, Sušnik A (2018) Tool for drought monitoring in the Danube region - methods and preliminary developments. J Environ Geogr 11(3-4):67-75. https://doi.org/10.2478/ jengeo-2018-0014

Cammalleri C, Vogt JV, Bisselink B, de Roo A (2017) Comparing soil moisture anomalies from multiple independent sources over 
different regions across the globe. Hydrol Earth Syst Sci 21:63296343. https://doi.org/10.5194/hess-21-6329-2017

Carrão H, Russo S, Sepulcre-Canto G, Barbosa P (2016) An empirical standardized soil moisture index for agricultural drought assessment from remotely sensed data. Int J Appl Earth Obs Geoinf 48:74-84. https://doi.org/10.1016/j.jag.2015.06.011

Ceglar A, Croitoru A-E, Cuxart J, Djurdjevic V, Güttler I et al (2018) PannEx: the Pannonian Basin experiment. Climate Serv 11:78-85. https://doi.org/10.1016/j.cliser.2018.05.002

Chaparro D, Piles M, Vall-llossera M, Camps A, Konings AG et al (2018) L-band vegetation optical depth seasonal metrics for crop yield assessment. Remote Sens Environ 212:249-259. https://doi.org/10. 1016/j.rse.2018.04.049

Chen X, Mo X, Zhang Y, Sun Z, Liu Y et al (2019) Drought detection and assessment with solar-induced chlorophyll fluorescence in summer maize growth period over North China Plain. Ecol Indic 104:347356. https://doi.org/10.1016/j.ecolind.2019.05.017

Cindrić K, Telišman Prtenjak M, Herceg-Bulić I, Mihajlović D, Pasarić Z (2016) Analysis of the extraordinary 2011/2012 drought in Croatia. Theor Appl Climatol 123:503-522. https://doi.org/10.1007/s00704014-1368-8

Cornes RC, van der Schrier G, van den Besselaar EJM, Jones PD (2018) An ensemble version of the E-OBS temperature and precipitation data sets. J Geophys Res Atmos 123:9391-9409. https://doi.org/10. 1029/2017JD028200

Croitoru A-E, Piticar A, Ciupertea A-F, Roșca CF (2016) Changes in heat waves indices in Romania over the period 1961-2015. Glob Planet Chang 146:109-121. https://doi.org/10.1016/j.gloplacha.2016.08. 016

Dorigo W, Wagner W, Albergel C, Albrecht F, Balsamo G et al (2017) ESA CCI soil moisture for improved earth system understanding: state-of-the art and future directions. Remote Sens Environ 203: 185-215. https://doi.org/10.1016/j.rse.2017.07.001

Dorigo WA, Zurita-Milla R, de Wit AJW, Brazile J, Singh R et al (2007) A review on reflective remote sensing and data assimilation techniques for enhanced agroecosystem modeling. Int J Appl Earth Obs Geoinf 9:165-193. https://doi.org/10.1016/j.jag.2006.05.003

Drüke M, Forkel M, von Bloh W, Sakschewski B, Cardoso M et al (2019) Improving the LPJmL4-SPITFIRE vegetation-fire model for South America using satellite data. Geosci Model Dev 12:5029-5054. https://doi.org/10.5194/gmd-12-5029-2019

Du L, Tian Q, Yu T, Meng Q, Jancso T et al (2013) A comprehensive drought monitoring method integrating MODIS and TRMM data. Int J Appl Earth Obs Geoinf 23:245-253. https://doi.org/10.1016/j. jag.2012.09.010

EDO (2018) EDO analytical reports, JRC European Drought Observatory (EDO), Drought in Central-Northern Europe July 2018, Drought in Central-Northern Europe August 2018. https://edo.jrc.ec.europa.eu/edov2/php/index.php?id=1051. Accessed 27 Mar 2020

EEA (2016) Biogeographical regions - European Environment Agency. https://www.eea.europa.eu/data-and-maps/data/biogeographicalregions-europe-3. Accessed 27 Mar 2020

Enenkel M, Steiner C, Mistelbauer T, Dorigo W, Wagner W et al (2016) A combined satellite-derived drought Indicator to support humanitarian aid organizations. Remote Sens 8:340. https://doi.org/10. $3390 /$ rs 8040340

Entekhabi D, Njoku EG, O’Neill PE, Kellogg KH, Crow WT et al (2010) The Soil Moisture Active Passive (SMAP) mission. Proc IEEE 98: 704-716. https://doi.org/10.1109/JPROC.2010.2043918

ESA (2017) Land cover CCI product user guide Version 2.0. http://maps. elie.ucl.ac.be/CCI/viewer/download/ESACCI-LC-Ph2-PUGv2_2. 0.pdf. Accessed 27 Mar 2020

Fiala K, Blanka V, Ladányi Z, Szilassi P, Benyhe B et al (2014) Drought severity and its effect on agricultural production in the Hungarian-
Serbian cross-border area. J Environ Geogr 7:43-51. https://doi.org/ 10.2478/jengeo-2014-0011

Forkel M, Andela N, Harrison SP, Lasslop G, van Marle M et al (2019) Emergent relationships with respect to burned area in global satellite observations and fire-enabled vegetation models. Biogeosciences 16:57-76. https://doi.org/10.5194/bg-16-57-2019

Govedarica M, Jovanović D, Sabo F, Borisov M, Vrtunski M et al (2016) Comparison of MODIS $250 \mathrm{~m}$ products for early corn yield predictions: a case study in Vojvodina, Serbia. Open Geosci 8:747-759. https://doi.org/10.1515/geo-2016-0070

Goward SN, Cruickshanks GD, Hope AS (1985) Observed relation between thermal emission and reflected spectral radiance of a complex vegetated landscape. Remote Sens Environ 18:137-146. https://doi. org/10.1016/0034-4257(85)90044-6

Gruber A, Dorigo WA, Crow W, Wagner W (2017) Triple collocationbased merging of satellite soil moisture retrievals. IEEE Trans Geosci Remote Sens 55:6780-6792. https://doi.org/10.1109/ TGRS.2017.2734070

Gruber A, Scanlon T, van der Schalie R, Wagner W, Dorigo W (2019) Evolution of the ESA CCI soil moisture climate data records and their underlying merging methodology. Earth Syst Sci Data 11:717739. https://doi.org/10.5194/essd-11-717-2019

Hao Z, AghaKouchak A, Nakhjiri N, Farahmand A (2014) Global integrated drought monitoring and prediction system. Scientific Data 1: 140001. https://doi.org/10.1038/sdata.2014.1

He M, Kimball JS, Maneta MP, Maxwell BD, Moreno A et al (2018) Regional crop gross primary productivity and yield estimation using fused Landsat-MODIS data. Remote Sens 10:372. https://doi.org/ $10.3390 /$ rs 10030372

Heidler K, Fietzke A (2019) Remote sensing for assessing drought insurance claims in central europe. In: IGARSS 2019-2019 IEEE International Geoscience and Remote Sensing Symposium. pp 7306-7309

Hlavinka P, Trnka M, Balek J, Semerádová D, Hayes M et al (2011) Development and evaluation of the SoilClim model for water balance and soil climate estimates. Agric Water Manag 98:1249-1261. https://doi.org/10.1016/j.agwat.2011.03.011

Hobbins MT, Wood A, McEvoy DJ, Huntington JL, Morton C et al (2016) The evaporative demand drought index. Part I: linking drought evolution to variations in evaporative demand. J Hydrometeorol 17:1745-1761. https://doi.org/10.1175/JHM-D-150121.1

Holmes TRH, Crow WT, Hain C, Anderson MC, Kustas WP (2015) Diurnal temperature cycle as observed by thermal infrared and microwave radiometers. Remote Sens Environ 158:110-125. https:// doi.org/10.1016/j.rse.2014.10.031

Hope AS, McDowell TP (1992) The relationship between surface temperature and a spectral vegetation index of a tallgrass prairie: effects of burning and other landscape controls. Int J Remote Sens 13: 2849-2863. https://doi.org/10.1080/01431169208904086

Hu X, Ren H, Tansey K, Zheng Y, Ghent D et al (2019) Agricultural drought monitoring using European Space Agency Sentinel 3A land surface temperature and normalized difference vegetation index imageries. Agric For Meteorol 279:107707. https://doi.org/10.1016/j. agrformet.2019.107707

Huang J, Gómez-Dans JL, Huang H, Ma H, Wu Q et al (2019) Assimilation of remote sensing into crop growth models: current status and perspectives. Agric For Meteorol 276-277:107609. https://doi.org/10.1016/j.agrformet.2019.06.008

Huete A, Didan K, Miura T, Rodriguez EP, Gao X et al (2002) Overview of the radiometric and biophysical performance of the MODIS vegetation indices. Remote Sens Environ 83:195-213. https://oi.org/ 10.1016/S0034-4257(02)00096-2

Hulley GC, Ghent D, Göttsche FM, Guillevic PC, Mildrexler DJ, et al (2019) 3 - Land surface temperature. In: Hulley GC, Ghent D (eds) 
Taking the temperature of the earth. Elsevier, pp. 57-127. https:// doi.org/10.1016/B978-0-12-814458-9.00003-4

ICPDR (2015) River Basin Management Plan - update 2015 | ICPDR International Commission for the Protection of the Danube River. https://www.icpdr.org/main/activities-projects/river-basinmanagement-plan-update-2015. Accessed 27 Mar 2020

IDMP (2018) IDMP for Central and Eastern Europe (IDMP CEE) | Integrated Drought Management Programme. http://www. droughtmanagement.info/idmp-activities/idmp_cee/. Accessed 27 Mar 2020

Immitzer M, Vuolo F, Atzberger C (2016) First experience with Sentinel2 data for crop and tree species classifications in Central Europe. Remote Sens 8:166. https://doi.org/10.3390/rs8030166

Jackson TJ, Cosh MH, Bindlish R, Starks PJ, Bosch DD et al (2010) Validation of advanced microwave scanning radiometer soil moisture products. IEEE Trans Geosci Remote Sens 48:4256-4272. https://doi.org/10.1109/TGRS.2010.2051035

Jakubínský J, Bláhová M, Bartošová L, Steinerová K, Balek J et al (2019) Repository of drought event impacts across the Danube catchment countries between 1981 and 2016 using publicly available sources. Acta Univ Agric Silvic Mendelianae Brun 67:925-938. https://doi. org/10.11118/actaun201967040925

Jiang Z, Huete AR, Didan K, Miura T (2008) Development of a two-band enhanced vegetation index without a blue band. Remote Sens Environ 112:3833-3845. https://doi.org/10.1016/j.rse.2008.06.006

Johnson DM (2016) A comprehensive assessment of the correlations between field crop yields and commonly used MODIS products. Int J Appl Earth Obs Geoinf 52:65-81. https://doi.org/10.1016/j. jag.2016.05.010

Johnson SJ, Stockdale TN, Ferranti L, Balmaseda MA, Molteni F et al (2019) SEAS5: the new ECMWF seasonal forecast system. Geosci Model Dev 12:1087-1117. https://doi.org/10.5194/gmd-12-10872019

Joiner J, Guanter L, Lindstrot R, Voigt M, Vasilkov AP et al (2013) Global monitoring of terrestrial chlorophyll fluorescence from moderate-spectral-resolution near-infrared satellite measurements: methodology, simulations, and application to GOME-2. Atmos Meas Tech 6:2803-2823. https://doi.org/10.5194/amt-6-2803-2013

Joiner J, Yoshida Y, Guanter L, Middleton EM (2016) New methods for the retrieval of chlorophyll red fluorescence from hyperspectral satellite instruments: simulations and application to GOME-2 and SCIAMACHY. Atmos Meas Tech 9:3939-3967. https://doi.org/ 10.5194/amt-9-3939-2016

Joiner J, Yoshida Y, Vasilkov AP, Schaefer K, Jung M et al (2014) The seasonal cycle of satellite chlorophyll fluorescence observations and its relationship to vegetation phenology and ecosystem atmosphere carbon exchange. Remote Sens Environ 152:375-391. https://doi. org/10.1016/j.rse.2014.06.022

Karnieli A, Agam N, Pinker RT, Anderson M, Imhoff ML et al (2010) Use of NDVI and land surface temperature for drought assessment: merits and limitations. J Clim 23:618-633. https://doi.org/10.1175/ 2009JCLI2900.1

Katul GG, Oren R, Manzoni S, Higgins C, Parlange MB (2012) Evapotranspiration: a process driving mass transport and energy exchange in the soil-plant-atmosphere-climate system. Rev Geophys 50. https://doi.org/10.1029/2011rg000366

Kern A, Barcza Z, Marjanović H, Árendás T, Fodor N et al (2018) Statistical modelling of crop yield in Central Europe using climate data and remote sensing vegetation indices. Agric For Meteorol 260-261:300-320. https://doi.org/10.1016/j.agrformet.2018.06.009

Kerr YH, Waldteufel P, Wigneron J-P, Delwart S, Cabot F et al (2010) The SMOS mission: new tool for monitoring key elements ofthe global water cycle. Proc IEEE 98:666-687. https://doi.org/10. 1109/JPROC.2010.2043032
Kim D, Rhee J (2016) A drought index based on actual evapotranspiration from the Bouchet hypothesis. Geophys Res Lett 43:10,277-10, 285. https://doi.org/10.1002/2016GL070302

Kogan FN (1995) Application of vegetation index and brightness temperature for drought detection. Adv Space Res 15:91-100. https:// doi.org/10.1016/0273-1177(95)00079-T

Kogan FN (2000) Satellite-observed sensitivity of world land ecosystems to El Niño/La Niña. Remote Sens Environ 74:445-462. https://doi. org/10.1016/S0034-4257(00)00137-1

Konings AG, Rao K, Steele-Dunne SC (2019) Macro to micro: microwave remote sensing of plant water content for physiology and ecology. New Phytol 223:1166-1172. https://doi.org/10.1111/nph. 15808

Kozak J, Björnsen Gurung A, Ostapowicz K (2011) Forum carpaticum. http://carpathianscience.org/documents/research-agenda/. Accessed 20 Mar 2020

Lawrimore J, Heim RR, Svoboda M, Swail V, Englehart PJ (2002) Beginning a new era of drought monitoring across North America. Bull Am Meteorol Soc 83:1191-1192. https://doi.org/10.1175/ 1520-0477-83.8.1191

Martens B, Miralles DG, Lievens H, van der Schalie R, de Jeu RAM et al (2017) GLEAM v3: satellite-based land evaporation and root-zone soil moisture. Geosci Model Dev 10:1903-1925. https://doi.org/10. 5194/gmd-10-1903-2017

Martínez-Fernández J, González-Zamora A, Sánchez N, Gumuzzio A (2015) A soil water based index as a suitable agricultural drought indicator. J Hydrol 522:265-273. https://doi.org/10.1016/j.jhydrol. 2014.12.051

Martínez-Fernández J, González-Zamora A, Sánchez N, Gumuzzio A, Herrero-Jiménez CM (2016) Satellite soil moisture for agricultural drought monitoring: assessment of the SMOS derived Soil Water Deficit Index. Remote Sens Environ 177:277-286. https://doi.org/ 10.1016/j.rse.2016.02.064

Martínez-Fernández J, González-Zamora A, Sánchez N, Pablos M (2017) CCI soil moisture for long-term agricultural drought monitoring: a case study in Spain. In: 2017 IEEE International Geoscience and Remote Sensing Symposium (IGARSS). pp 1985-1988

Mathieu JA, Aires F (2018a) Using neural network classifier approach for statistically forecasting extreme corn yield losses in eastern United States. Earth Space Sci 5:622-639. https://doi.org/10.1029/ 2017EA000343

Mathieu JA, Aires F (2018b) Assessment of the agro-climatic indices to improve crop yield forecasting. Agric For Meteorol 253-254:15-30. https://doi.org/10.1016/j.agrformet.2018.01.031

Mazdiyasni O, AghaKouchak A (2015) Substantial increase in concurrent droughts and heatwaves in the United States. PNAS 112: 11484-11489. https://doi.org/10.1073/pnas.1422945112

McKee TB, Doesken NJ, Kleist J (1993) The Relationship of Drought Frequency and Duration to Time Scales. Proceedings of the Eighth Conference on Applied Climatology. Am Meteorol Soc pp. 179184

McVicar TR, Bierwirth PN (2001) Rapidly assessing the 1997 drought in Papua New Guinea using composite AVHRR imagery. Int J Remote Sens 22:2109-2128. https://doi.org/10.1080/01431160120728

McVicar TR, Roderick ML, Donohue RJ, Li LT, Van Niel TG et al (2012) Global review and synthesis of trends in observed terrestrial near-surface wind speeds: implications for evaporation. J Hydrol 416-417:182-205. https://doi.org/10.1016/j.jhydrol.2011.10.024

Metzger MJ (2018) The environmental stratification of Europe, [dataset]. University of Edinburgh. https://doi.org/10.7488/ds/2356

Miralles DG, van den Berg MJ, Gash JH, Parinussa RM, de Jeu RAM et al (2014) El Niño-La Niña cycle and recent trends in continental evaporation. Nat Clim Chang 4:122-126. https://doi.org/10.1038/ nclimate2068

Miralles DG, Gentine P, Seneviratne SI, Teuling AJ (2019) Landatmospheric feedbacks during droughts and heatwaves: state of the 
science and current challenges. Ann N Y Acad Sci 1436:19-35. https://doi.org/10.1111/nyas.13912

Miralles DG, Holmes TRH, Jeu RAMD, Gash JH, Meesters AGCA et al (2011) Global land-surface evaporation estimated from satellitebased observations. Hydrol Earth Syst Sci 15:453-469. https://doi. org/10.5194/hess-15-453-2011

Mishra A, Vu T, Veettil AV, Entekhabi D (2017) Drought monitoring with soil moisture active passive (SMAP) measurements. J Hydrol 552:620-632. https://doi.org/10.1016/j.jhydrol.2017.07.033

Mishra AK, Singh VP (2010) A review of drought concepts. J Hydrol 391:202-216. https://doi.org/10.1016/j.jhydrol.2010.07.012

Moesinger L, Dorigo W, de Jeu R, van der Schalie R, Scanlon T et al (2019a) The global long-term microwave vegetation optical depth climate archive VODCA. Earth Syst Sci Data Discuss:1-26. https:// doi.org/10.5194/essd-2019-42

Moesinger L, Dorigo W, Jeu R de, Schalie R van der, Scanlon T, et al (2019b) The global long-term microwave vegetation optical depth climate archive VODCA. Zenodo 1.0: https://doi.org/10.5281/ zenodo. 2575599

Mohammed GH, Colombo R, Middleton EM, Rascher U, van der Tol C et al (2019) Remote sensing of solar-induced chlorophyll fluorescence (SIF) in vegetation: 50 years of progress. Remote Sens Environ 231:111177. https://doi.org/10.1016/j.rse.2019.04.030

Mu Q, Zhao M, Kimball JS, McDowell NG, Running SW (2012) A remotely sensed global terrestrial drought severity index. Bull Am Meteorol Soc 94:83-98. https://doi.org/10.1175/BAMS-D-1100213.1

Mu Q, Zhao M, Running SW (2013) MODIS global terrestrial evapotranspiration (ET) product (NASA MOD16A2/A3) collection 5. NASA Headquarters Numerical Terradynamic Simulation Group Publications 67

Nagy A, Fehér J, Tamás J (2018) Wheat and maize yield forecasting for the Tisza river catchment using MODIS NDVI time series and reported crop statistics. Comput Electron Agric 151:41-49. https:// doi.org/10.1016/j.compag.2018.05.035

Norman JM, Kustas WP, Humes KS (1995) Source approach for estimating soil and vegetation energy fluxes in observations of directional radiometric surface temperature. Agric For Meteorol 77:263-293. https://doi.org/10.1016/0168-1923(95)02265-Y

Olesen JE, Trnka M, Kersebaum KC, Skjelvåg AO, Seguin B et al (2011) Impacts and adaptation of European crop production systems to climate change. Eur J Agron 34:96-112. https://doi.org/10.1016/j. eja.2010.11.003

Orhan O, Ekercin S, Dadaser-Celik F (2014) Use of Landsat land surface temperature and vegetation indices for monitoring drought in the salt Lake Basin area, Turkey. In: The Scientific World Journal. https:// www.hindawi.com/journals/tswj/2014/142939/. Accessed 19 Apr 2020

Owe M, de Jeu R, Walker J (2001) A methodology for surface soil moisture and vegetation optical depth retrieval using the microwave polarization difference index. IEEE Trans Geosci Remote Sens 39(8):1643-1654. https://doi.org/10.1109/36.942542

Palmer WC (1965) Meteorological drought. Research Paper, US Weather Bureau, Washington DC 58

Papagiannopoulou C, Miralles DG, Decubber S, Demuzere M, Verhoest NEC et al (2017) A non-linear Granger-causality framework to investigate climate-vegetation dynamics. Geosci Model Dev 10: 1945-1960. https://doi.org/10.5194/gmd-10-1945-2017

Pfeil I, Wagner W, Forkel M, Dorigo W, Vreugdenhil M (2020) Does ASCAT observe the spring reactivation in temperate deciduous broadleaf forests? Remote Sens Environ 250:112042. https://doi. org/10.1016/j.rse.2020.112042

Rebetez M, Mayer H, Dupont O, Schindler D, Gartner K et al (2006) Heat and drought 2003 in Europe: a climate synthesis. Ann For Sci 63: 569-577. https://doi.org/10.1051/forest:2006043
Reichstein M, Camps-Valls G, Stevens B, Jung M, Denzler J et al (2019) Deep learning and process understanding for data-driven Earth system science. Nature 566:195-204. https://doi.org/10.1038/s41586019-0912-1

Rossi S, Weissteiner C, Laguardia G, Kurnik B, Robustelli M, et al (2008) Potential of MERIS fAPAR for drought detection. Proceedings of the 2nd MERIS/(A) ATSR User Workshop ESASP-666:6

Sánchez N, González-Zamora Á, Piles M, Martínez-Fernández J (2016) A new Soil Moisture Agricultural Drought Index (SMADI) integrating MODIS and SMOS products: a case of study over the Iberian Peninsula. Remote Sens 8:287. https://doi.org/10.3390/rs8040287

Seneviratne SI (2012) Historical drought trends revisited. Nature 491: 338-339. https://doi.org/10.1038/491338a

Shafer BA, Dezman LE (1982) Development of a surface water supply index (SWSI) to assess the severity of drought conditions in snowpack runoff areas. Proceedings of the Western Snow Conference, pp. 164-175. https://westernsnowconference.org/node/932. Accessed 24 Mar 2020

Sheffield J, Wood EF, Chaney N, Guan K, Sadri S et al (2013) A drought monitoring and forecasting system for sub-Sahara African water resources and food security. Bull Am Meteorol Soc 95:861-882. https://doi.org/10.1175/BAMS-D-12-00124.1

Sippel S, Forkel M, Rammig A, Thonicke K, Flach M et al (2017) Contrasting and interacting changes in simulated spring and summer carbon cycle extremes in European ecosystems. Environ Res Lett 12:075006. https://doi.org/10.1088/1748-9326/aa7398

Sippel S, Reichstein M, Ma X, Mahecha MD, Lange H et al (2018) Drought, heat, and the carbon cycle: a review. Curr Clim Change Rep 4:266-286. https://doi.org/10.1007/s40641-018-0103-4

Sohrabi MM, Ryu JH, John A, John T (2015) Development of soil moisture drought index to characterize droughts. J Hydrol Eng 20: 04015025. https://doi.org/10.1061/(ASCE)HE.1943-5584.0001213

Spinoni J, Antofie T, Barbosa P, Bihari Z, Lakatos M, et al (2013) An overview of drought events in the Carpathian Region in 1961-2010. In: Advances in science and research. Copernicus GmbH, pp. 21-32

Spinoni J, Lakatos M, Szentimrey T, Bihari Z, Szalai S et al (2015) Heat and cold waves trends in the Carpathian region from 1961 to 2010. Int J Climatol 35:4197-4209. https://doi.org/10.1002/joc.4279

Spinoni J, Naumann G, Vogt JV (2017) Pan-European seasonal trends and recent changes of drought frequency and severity. Glob Planet Chang 148:113-130. https://doi.org/10.1016/j.gloplacha.2016.11. 013

Sridhar V, Hubbard KG, You J, Hunt ED (2008) Development of the Soil Moisture Index to quantify agricultural drought and its "user friendliness" in severity-area-duration assessment. J Hydrometeorol 9: 660-676. https://doi.org/10.1175/2007JHM892.1

Štěpánek P, Trnka M, Chuchma F, Zahradníček P, Skalák P et al (2018) Drought prediction system for Central Europe and its validation. Geosciences 8:104. https://doi.org/10.3390/geosciences8040104

Sun Y, Frankenberg C, Jung M, Joiner J, Guanter L et al (2018) Overview of Solar-Induced chlorophyll Fluorescence (SIF) from the Orbiting Carbon Observatory-2: retrieval, cross-mission comparison, and global monitoring for GPP. Remote Sens Environ 209:808-823. https://doi.org/10.1016/j.rse.2018.02.016

Svoboda M, LeComte D, Hayes M, Heim R, Gleason K et al (2002) The drought monitor. Bull Am Meteorol Soc 83:1181-1190. https://doi. org/10.1175/1520-0477-83.8.1181

Teubner IE, Forkel M, Camps-Valls G, Jung M, Miralles DG et al (2019) A carbon sink-driven approach to estimate gross primary production from microwave satellite observations. Remote Sens Environ 229: 100-113. https://doi.org/10.1016/j.rse.2019.04.022

Trnka M, Hlavinka P, Možný M, Semerádová D, Štěpánek P et al (2020) Czech drought monitor system for monitoring and forecasting agricultural drought and drought impacts. Int J Climatol. https://doi.org/ $10.1002 /$ joc. 6557 
Trnka M, Hlavinka P, Semenov MA (2015) Adaptation options for wheat in Europe will be limited by increased adverse weather events under climate change. J R Soc Interface 12:20150721. https://doi.org/10. 1098/rsif.2015.0721

Trnka M, Rötter RP, Ruiz-Ramos M, Kersebaum KC, Olesen JE et al (2014) Adverse weather conditions for European wheat production will become more frequent with climate change. Nat Clim Chang 4: 637-643. https://doi.org/10.1038/nclimate2242

Tucker CJ (1979) Red and photographic infrared linear combinations for monitoring vegetation. Remote Sens Environ 8:127-150. https:// doi.org/10.1016/0034-4257(79)90013-0

Van Lanen HAJ, Laaha G, Kingston DG, Gauster T, Ionita M et al (2016) Hydrology needed to manage droughts: the 2015 European case. Hydrol Process 30:3097-3104. https://doi.org/10.1002/hyp.10838

Vicente-Serrano SM, Beguería S, López-Moreno JI (2009) A multiscalar drought index sensitive to global warming: the Standardized Precipitation Evapotranspiration Index. J Clim 23:1696-1718. https://doi.org/10.1175/2009JCLI2909.1

Vicente-Serrano SM, Beguería S, Lorenzo-Lacruz J, Camarero JJ, LópezMoreno JI et al (2012) Performance of drought indices for ecological, agricultural, and hydrological applications. Earth Interact 16:127. https://doi.org/10.1175/2012EI000434.1

Vreugdenhil M, Dorigo WA, Wagner W, de Jeu RAM, Hahn S et al (2016) Analyzing the vegetation parameterization in the TU-Wien ASCAT soil moisture retrieval. IEEE Trans Geosci Remote Sens 54: 3513-3531. https://doi.org/10.1109/TGRS.2016.2519842

Vreugdenhil M, Wagner W, Bauer-Marschallinger B, Pfeil I, Teubner I et al (2018) Sensitivity of Sentinel-1 backscatter to vegetation dynamics: an Austrian case study. Remote Sens 10:1396. https://doi. org $/ 10.3390 /$ rs 10091396

Wardlow B, Anderson M, Verdin J (Eds) (2012) Remote sensing of drought. CRC Press, Boca Raton. https://doi.org/10.1201/b11863

Wells N, Goddard S, Hayes MJ (2004) A self-calibrating Palmer Drought Severity Index. J Clim 17:2335-2351. https://doi.org/10.1175/ 1520-0442(2004)017<2335:ASPDSI $>2.0 . C O ; 2$

West H, Quinn N, Horswell M (2019) Remote sensing for drought monitoring \& impact assessment: progress, past challenges and future opportunities. Remote Sens Environ 232:111291. https://doi.org/10. 1016/j.rse.2019.111291

Wilhite D, Wilhite D (eds) (2000) Droughts. Routledge, London. https:// doi.org/10.4324/9781315830896

Wilhite DA, Glantz MH (1985) Understanding: the drought phenomenon: the role of definitions. Water Int 10:111-120. https://doi.org/ $10.1080 / 02508068508686328$
Xu Y, Wang L, Ross KW, Liu C, Berry K (2018) Standardized Soil Moisture Index for drought monitoring based on soil moisture active passive observations and 36 years of North American land data assimilation system data: a case study in the Southeast United States. Remote Sens 10:301. https://doi.org/10.3390/rs10020301

Xue J, Su B (2017) Significant remote sensing vegetation indices: a review of developments and applications. In: Journal of Sensors. https://www.hindawi.com/journals/js/2017/1353691/. Accessed 25 Mar 2020

Yang H, Wang H, Fu G, Yan H, Zhao P et al (2017) A modified soil water deficit index (MSWDI) for agricultural drought monitoring: case study of Songnen Plain, China. Agric Water Manag 194:125-138. https://doi.org/10.1016/j.agwat.2017.07.022

Zahradníček P, Trnka M, Brázdil R, Možný M, Štěpánek P et al (2015) The extreme drought episode of August 2011-May 2012 in the Czech Republic. Int J Climatol 35:3335-3352. https://doi.org/10. $1002 /$ joc.4211

Zhang K, Kimball JS, Running SW (2016) A review of remote sensing based actual evapotranspiration estimation. WIREs Water 3:834 853. https://doi.org/10.1002/wat2.1168

Zhang L, Yao Y, Bei X, Jia K, Zhang X et al (2019) Assessing the remotely sensed Evaporative Drought Index for drought monitoring over Northeast China. Remote Sens 11:1960. https://doi.org/10. 3390/rs11171960

Zhou S, Williams AP, Berg AM, Cook BI, Zhang Y et al (2019) Landatmosphere feedbacks exacerbate concurrent soil drought and atmospheric aridity. PNAS 116:18848-18853. https://doi.org/10.1073/ pnas. 1904955116

Zhu Q, Luo Y, Xu Y-P, Tian Y, Yang T (2019) Satellite soil moisture for agricultural drought monitoring: assessment of SMAP-derived Soil Water Deficit Index in Xiang River Basin, China. Remote Sens 11: 362. https://doi.org/10.3390/rs11030362

Zink M, Samaniego L, Kumar R, Thober S, Mai J et al (2016) The German drought monitor. Environ Res Lett 11:074002. https://doi. org/10.1088/1748-9326/11/7/074002

Zscheischler J, Westra S, van den Hurk BJJM, Seneviratne SI, Ward PJ et al (2018) Future climate risk from compound events. Nat Clim Chang 8:469. https://doi.org/10.1038/s41558-018-0156-3

Publisher's note Springer Nature remains neutral with regard to jurisdictional claims in published maps and institutional affiliations.

\section{Affiliations}

\section{Laura Crocetti ${ }^{1}$ (D) Matthias Forkel ${ }^{2} \cdot$ Milan Fischer $^{3} \cdot$ František Jurečka $^{3} \cdot$ Aleš Grlj $^{4,5} \cdot$ Andreas Salentinig $^{1}$. Miroslav Trnka $^{3,6} \cdot$ Martha Anderson $^{7} \cdot$ Wai-Tim Ng ${ }^{8} \cdot$ Žiga Kokalj $^{4,5} \cdot$ Andreea Bucur $^{1} \cdot$ Wouter Dorigo ${ }^{1}$}

1 Department of Geodesy and Geoinformation, TU Wien, Wiedner Hauptstraße 8-10, 1040 Vienna, Austria

2 Institute of Photogrammetry and Remote Sensing, TU Dresden, Chemnitzer Straße 50, 01187 Dresden, Germany

3 Global Change Research Institute CAS, CzechGlobe, Bělidla 986/ 4a, 60300 Brno, Czech Republic

4 SPACE-SI, Slovenian Centre of Excellence for Space Sciences and Technologies, Aškerčeva 12, 1000 Ljubljana, Slovenia
5 Institute of Anthropological and Spatial Studies, ZRC SAZU, Novi Trg 2, 1000 Ljubljana, Slovenia

6 Department of Agrosystems and Bioclimatology, Mendel University in Brno, Zemědělská 1, 61300 Brno, Czech Republic

7 Hydrology and Remote Sensing Laboratory, USDA-ARS, Beltsville, MD 20705, USA

$8 \quad$ EODC - Earth Observation Data Centre for Water Resources Monitoring, Franz-Grill-Straße 9, 1030 Vienna, Austria 